\title{
Probabilistic estimation of future emissions of isoprene and surface oxidant chemistry associated with land- use change in response to growing food needs
}

\author{
C. J. Hardacre ${ }^{1, *}$, P. I. Palmer ${ }^{1}$, K. Baumanns ${ }^{2}$, M. Rounsevell ${ }^{1}$, and D. Murray-Rust ${ }^{1}$ \\ ${ }^{1}$ School of GeoSciences, University of Edinburgh, Edinburgh, UK \\ ${ }^{2}$ Department of Geography and Ecosystem Science, Lund University, Lund, Sweden \\ *now at: The Lancaster Environment Centre, University of Lancaster, Lancaster, UK \\ Correspondence to: P. I. Palmer (pip@ed.ac.uk)
}

Received: 12 December 2012 - Published in Atmos. Chem. Phys. Discuss.: 21 December 2012 Revised: 9 April 2013 - Accepted: 23 April 2013 - Published: 3 June 2013

\begin{abstract}
We quantify the impact of land-use change, determined by our growing demand for food and biofuel production, on isoprene emissions and subsequent atmospheric oxidant chemistry in 2015 and 2030, relative to 1990, ignoring compound climate change effects over that period. We estimate isoprene emissions from an ensemble $(n=1000)$ of land-use change realizations from 1990-2050, broadly guided by the IPCC AR4/SRES scenarios A1 and B1. We also superimpose land-use change required to address projected biofuel usage using two scenarios: (1) assuming that world governments make no changes to biofuel policy after 2009, and (2) assuming that world governments develop biofuel policy with the aim of keeping equivalent atmospheric $\mathrm{CO}_{2}$ at $450 \mathrm{ppm}$. We present the median and interquartile range (IQR) statistics of the ensemble and show that landuse change between $-1.50 \times 10^{12} \mathrm{~m}^{2}$ to $+6.06 \times 10^{12} \mathrm{~m}^{2}$ was found to drive changes in the global isoprene burden of -3.5 to $+2.8 \mathrm{Tg} \mathrm{yr}^{-1}$ in 2015 and -7.7 to $+6.4 \mathrm{Tg} \mathrm{yr}^{-1}$ in 2030. We use land-use change realizations corresponding to the median and IQR of these emission estimates to drive the GEOS-Chem global 3-D chemistry transport model to investigate the perturbation to global and regional surface concentrations of isoprene, nitrogen oxides $\left(\mathrm{NO}+\mathrm{NO}_{2}\right)$, and the atmospheric concentration and deposition of ozone $\left(\mathrm{O}_{3}\right)$. We show that across subcontinental regions the monthly surface $\mathrm{O}_{3}$ increases by $0.1-0.8 \mathrm{ppb}$, relative to a zero land-use change calculation, driven by increases (decreases) in surface isoprene in high (low) $\mathrm{NO}_{\mathrm{x}}$ environments. At the local scale $\left(4^{\circ} \times 5^{\circ}\right)$ we find that surface $\mathrm{O}_{3}$ increases by $5-12 \mathrm{ppb}$ over
\end{abstract}

temperate North America, China and boreal Eurasia, driven by large increases in isoprene emissions from short-rotation coppice crop cultivation for biofuel production.

\section{Introduction}

Expanding food production to feed a growing population will unavoidably result in significant changes in land-use (Balmford et al., 2005; Foley et al., 2011; Tilman et al., 2011; Godfray et al., 2010), with far-reaching implications for local climate through shifts in radiation, cloudiness and surface temperatures (Barth et al., 2005; Brovkin et al., 2006; Scanlon et al., 2005; IPCC, 2007). Here, we focus on the resulting perturbation to the distribution, and magnitude of biogenic volatile organic compound (BVOC) emissions (in particular isoprene) and consequently changes to surface ozone, which at elevated concentrations can lead to reduced crop productivity.

The degree to which agricultural land (crop land and pastures) will need to expand is highly uncertain. Previous work that used different methods and assumptions have suggested estimates between $+2 \%$ and $+56 \%$ by 2050 relative to values in 2000 (IPCC/SRES, 2000; Tilman et al., 2001, 2011; Balmford et al., 2005). In some socioeconomic projections from the fourth Assessment Report (AR4) from the Intergovernmental Panel on Climate Change (IPCC) Special Report on Emissions Scenarios (SRES) (hereinafter referred to as IPCC AR4/SRES) the required agricultural land in 2050 
decreases relative to 2000 but this is generally believed to be an unlikely outcome (IPCC/SRES, 2000; Balmford et al., 2005). Some demand for agricultural land may be satisfied by (1) developing abandoned and marginal lands for cultivation (e.g. Europe and United States, Tilman et al., 2001) and (2) closing the yield gap between developed and developing nations by, for example, applying technological development (Beddington, 2010; Foley et al., 2011). However, despite these measures new agricultural land will have to be converted from natural grasslands and forest.

The increased demand for biofuels will also likely impact land-use change (LUC). In an effort to curb greenhouse gas emissions and to increase fuel security many countries have now set targets for blending biofuel in transport fuel. For example, the current European Union target is for 5.75\% biofuel in transport fuel, Indonesia aims to include $10 \%$ biofuel in transport fuel by 2015 and Brazil aims for 25-30\% biofuel in transport fuel although no target date is specified (International Energy Agency, 2011). Estimates of LUC associated with biofuel production are uncertain. Biofuel production technologies are in many cases relatively expensive and are still in the developmental phase. Biofuel production is highly dependent on oil prices, government policy and the uncertainty surrounding the effect of indirect LUC (Searchinger et al., 2008; Gallagher, 2008; Howarth et al., 2009).

The impacts of LUC due to expansion of food and biofuel/bioenergy production on BVOC emissions and surface air quality have been investigated in several previous studies. A recent model study showed that the largest decreases $(15 \%)$ in isoprene emissions in the 20th century were due to the anthropogenic expansion of cropland (Lathiere et al., 2010). Recent field-based work has shown that the basal BVOC emissions of some biofuel crops, particularly oil palm, can be many times higher than the indigenous crops that they replace (e.g. Fowler et al., 2011; Copeland et al., 2012). Further, a modelling study showed that replacing existing agricultural crops with oil palm and short-rotation coppice (SRC) crops (e.g. willow (Salix spp.), poplar (Populus spp.) and eucalyptus (Eucalyptus spp.)), for increased biofuel production resulted in large surface ozone changes at local and regional scales (Ashworth et al., 2012); although on a global scale surface ozone was not perturbed significantly. In that study the expansion of oil palm cultivation in Southeast Asia lead to increases in the annual mean surface ozone concentration of up to $11 \%$. Over Europe the increases in annual mean surface ozone concentrations, due to increased SRC crop cultivation, were smaller $(<1 \%)$. Other work that used LUC informed by the AR4/SRES A1B storyline also found only small changes in the global atmospheric burden of surface ozone, although changes in the surface BVOC burden were larger, due to the combined impacts from agricultural LUC and climate driven vegetation change over 20002100 (Wu et al., 2012). This study found significant regional changes (Wu et al., 2012). In the period 2000-2050, this study noted increased agricultural land use and subsequent decreases in surface isoprene in the eastern USA, South Asia and Central Africa. Associated with this LUC, surface ozone increased over South Asia and Central Africa, but decreased in the USA where the $\mathrm{NO}_{\mathrm{x}}\left(\mathrm{NO}+\mathrm{NO}_{2}\right)$ abundance is relatively high. Beyond 2050 the land use associated with agricultural cultivation decreases in Central Africa and South Asia as the global population peaks following the SRES storyline, with an associated increase in surface isoprene and a decrease in surface ozone. In contrast, Amazonian agricultural land area increases between 2050 and 2100 with a related increase in surface ozone.

Future LUC scenarios, and subsequent climate impacts, developed around a storyline are typically investigated using integrated assessment models (IAMs) (Lambin et al., 2000; Heistermann et al., 2006). The IAMs generally have a comprehensive list of components that aim to incorporate a wide range of sectors and process descriptions. The uncertainty associated with any individual components and the interactions between them are largely unquantified. The other major disadvantage of this approach, due to the associated computational overhead, is that they can only run for a very small number of experiments, limiting any sensitivity study. As part of a larger project, we have developed a simplified system dynamics model of LUC (PLUM, the Parsimonious Land Use Model) that can still reproduce the broadest observed global and regional changes in agricultural land use (represented by crop land and pastures) from 1990-2010 (Baumanns et al., 2013). The major advantage of this approach is that we can study the ensemble characteristics of the problem, accounting for uncertainties in our assumptions, rather than studying one realization of the model. We describe PLUM in Sect. 2. In this paper, we have taken the output from 1000 ensemble runs of PLUM that describe how land-use changes from 1990 to 2050 in five-year increments and calculate the corresponding isoprene emissions based on data described by the Model of Emissions of Gases and Aerosols from Nature (MEGAN) BVOC emission model (Guenther et al., 2006), described in Sect. 2. In Sect. 3, we present and discuss our findings. As part of our analysis we look at the mean statistics of the MEGAN ensemble of isoprene emissions and use the median and interquartile range (IQR) statistics to drive the GEOS-Chem global 3-D chemistry transport model to investigate the corresponding change in surface level ozone in 2015 and 2030 (Sect. 2). We conclude the paper in Sect. 4.

\section{Methods}

Figure 1 provides an overview of the methods we use in this paper to link LUC estimates to BVOC emissions and subsequently to atmospheric chemistry. In steps 1 through 3 , we use two of the IPCC AR4/SRES scenarios (A1 and $\mathrm{B} 1$, Table 1$)$ to generate an ensemble $(n=1000$ per scenario $=2000$ ) of future LUC realizations using the PLUM 


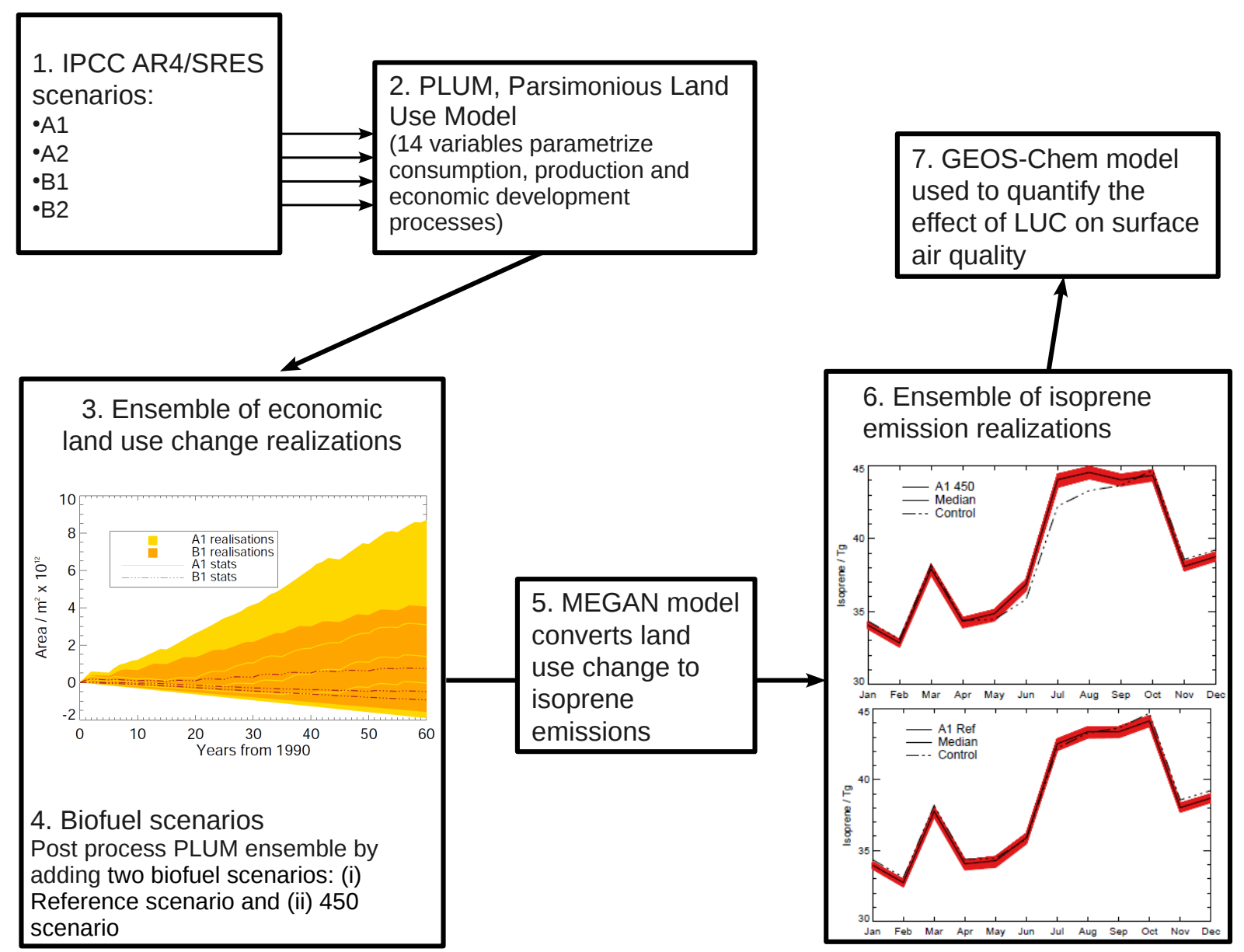

Fig. 1. Schematic illustrating the overall methodology used in our study to determine probabilistic estimates of changes in BVOC emissions and surface ozone from ensemble LUC estimates from a simplified system dynamics model.

model. We retain the 500 realizations that define the IQR for each scenario $(n=500$ per scenario $=1000)$. In step 4 , we augment our LUC realizations with two biofuel scenarios $(2 \times n=2000)$ that describe (i) no change in energy policy after 2009 (Reference scenario), and (ii) policies that keep the equivalent atmospheric $\mathrm{CO}_{2}$ below $450 \mathrm{ppm}$ (450 scenario). In step 5 we use the biofuel scenarios and the LUC realizations to determine the corresponding spatial changes in BVOC basal emissions using the MEGAN model. We make several assumptions in step 4 when we assess LUC from biofuel feed stock cultivation (detailed in Sect. 2.2) compared to the detailed ensemble of LUC realizations from PLUM. However, it was necessary to initially investigate a large number of these realizations to assess their effect on global BVOC emissions. We also consider changes in soil $\mathrm{NO}_{\mathrm{x}}$ emissions and deposition fluxes associated with the changes in land cover. We use the realizations that define the median and range of the global variation in BVOC basal emissions to reduce the ensemble size for the GEOS-Chem global 3D chemistry transport model calculation: (i) quantifying iso- prene emissions and (ii) oxidant chemistry associated with these perturbed emissions.

\subsection{Land-use change due to changes in food consumption}

PLUM is a simplified system dynamics model that determines change in global land cover at the country level. LUC in PLUM is primarily driven by changes in consumption of commodities (represented in PLUM by cereals, meat and milk) and technological change resulting in yield improvements. The former is in turn driven by population and economic development and the latter is strongly influenced by the rate of technological change. The model also includes the exchange of commodities between countries within the global market. The consumption and production variables in PLUM are initialized with country level data from Food and Agriculture Organization Statistics (FAO, http://faostat.fao.org/). Country level data for economic development and population were retrieved from the Centre for International Earth Science Information Network CIESIN 
Table 1. Summary of the IPCC AR4/SRES scenario storylines.

\begin{tabular}{ll}
\hline Story line & Description \\
\hline A1 & $\begin{array}{l}\text { Convergent world in which knowledge and technologies are shared across regions with a resulting } \\
\text { decrease in regional differences in per capita income. Development of more efficient technologies } \\
\text { is rapid. Global population peaks in mid-century and declines thereafter. }\end{array}$ \\
\hline A2 & $\begin{array}{l}\text { Divergent world where local identity is preserved and economic development is regionally ori- } \\
\text { ented. The global population increases continually as a result of very slow convergence of fertility } \\
\text { patterns. }\end{array}$ \\
\hline B1 & $\begin{array}{l}\text { Convergent world with a population that peaks mid-century. Economies become service and in- } \\
\text { formation based and there is emphasis on clean, efficient technologies and improved equity. }\end{array}$ \\
\hline B2 & $\begin{array}{l}\text { Divergent storyline with emphasis on environmental protection and social equity, however, local } \\
\text { rather than global solutions are sought, with the result that technological change is slower and } \\
\text { more diverse compared to A1 and B1. Global population increases continually, but at a lower rate } \\
\text { than A2. }\end{array}$ \\
\hline
\end{tabular}

(2002). Countries for which FAOSTAT and CIESIN data were not available, including Democratic Republic of the Congo, Iraq, Afghanistan, Somalia, Oman and small island/city states, were not included in PLUM. PLUM is implemented using the visual modelling environment, Simile (Muetzelfeldt and Massheder, 2003). We provide a brief description of PLUM below and refer the reader to Baumanns et al. (2013) for further information.

PLUM comprises three modules which describe (i) socioeconomics and consumption, (ii) conversion and trade, and (iii) land conversion. The socioeconomic module describes how population development and economic activity change the consumption of commodities. Economic activity, represented by gross domestic product (GDP) per capita, differentiates the rates of change for processes such as consumption (of meat, milk and cereals) or yield improvements across high, middle and low income countries. Changes in cereal consumption are assumed to be proportional to changes in population. In low income countries meat and milk consumption increases slowly. In middle and high income countries meat and milk consumption increases rapidly until a saturation level is reached. Cultural patterns of meat and milk consumption are accounted for by dividing countries into four consumption classes. For example countries which have high income levels, but low meat consumption, such as Japan and Norway, form one class.

The conversion and trade module describes the demand for cereal-based products for animal feed as a result of the amount of meat and milk consumption. For each year the cereal balance (consumption minus production) is determined for each individual country. If the balance is negative, cereal is imported to that country, while countries with a positive balance are assumed to export. Production in an individual country takes account of that country's cereal balance and the world cereal balance, through which all countries are connected. If the world cereal balance is positive, export- ing countries are assumed to gradually decrease production, while production in importing countries remains unchanged. If the world cereal balance is negative exporting and importing countries attempt to increase their production.

The land conversion module determines the area of forest and grassland within a country that is converted to crop land (or vice versa) to meet increased (or decreased) demand for cereal production within that country, taking into account cereal yields. To exclude implausibly high rates of LUC, a scenario-dependent maximum rate of LUC is defined. LUC in PLUM is strongly influenced by the cereal yield which is assumed to be linked to technological development.

Consumption, production, technological development and land conversion in PLUM are parameterized across 14 variables, some of which, for example, meat consumption as described above, are further divided into classes. The parsimonious nature of PLUM allows for the efficient exploration of uncertainty in LUC in a probabilistic manner.

Simulations of future LUC were developed based on four socioeconomic projections from the IPCC SRES activity (Gaffin et al., 2004; CIESIN, 2002). Table 1 outlines the themes of these four scenarios, A1, B1, A2, B2 (summarized from IPCC/SRES, 2000). For each scenario an ensemble of 1000 LUC realizations were generated from 1990 to 2050 by perturbing PLUM variables uniformly within a fixed range that was consistent with each IPCC-SRES scenario (Baumanns et al., 2013). For example, greater rates of increase in food consumption were explored for the A1 scenario (a high emission scenario) compared to the B1 scenario (a low emission scenario), where the range of low rates for food consumption in combination with decreasing population growth resulted in decreasing cereal consumption.

We focus on scenarios A1, allowing us to compare our results with recent studies, and B1 that uses the same assumptions about changes in population, but different assumptions about economics therefore providing a contrast to A1. We 
focus our analysis on years 2015 and 2030, representing short- and medium-term projections respectively. We have chosen to focus on the short and medium term for two reasons. First, we want to produce estimates that can be used to inform policy now and are generally falsifiable in our lifetimes. Second, our models, and indeed the SRES scenarios, have been linearized about a state that typifies previous decades that could easily be seen as different from those beyond 2030 when many components (and their interactions) of the earth system could be forced into new states.

\subsection{Land-use change due to changes in biofuel consumption}

We consider the expansion of agricultural area for biofuel cultivation using two International Energy Agency scenarios: (1) the "Reference" scenario in which we assume that governments make no changes to energy policies after 2009; and (2) the "450" scenario which describes collective policy action that would keep equivalent atmospheric $\mathrm{CO}_{2}$ at $450 \mathrm{ppm}$ (World Energy Outlook, 2009, p. 41; International Energy Agency, 2010, p. 27). Both biofuel futures are predicted to 2030 and estimate that biofuel will contribute 160 billion $\mathrm{L}$ ("Reference") and 349 billion L ("450"), respectively, to the total transport fuel demand. The reference scenario assumes $75 \%$ of biofuel will be produced from first generation feed stocks, $25 \%$ will be produced from second generation feed stocks and that no residue/waste feedstocks will be used. The 450 scenario predicts $50: 50$ first and second generation feedstocks, with residue/waste feedstock being important. We do not consider LUC due to bioenergy demands because estimates are too uncertain, reflecting poor quantification of current usage. In this study we define first and second generation biofuels according to the International Energy Agency (2008). First generation biofuels are primarily produced from food crops such as grains and sugar beet for bioethanol and oil seed crops (e.g. oil palm) for biodiesel. Second generation biofuels are produced from non-food biomass for which the feed stocks are generally lignocellulosic materials including forest residues and purpose grown energy crops from which the end product is usually bioethanol.

First generation feedstocks currently grown for commercial biofuel production include sugarcane (Saccharum spp.), sugar beet (Beta vulgaris), cassava (Manihot esculenta) and maize (Zea mays) for bioethanol production, and oil palm (Elaeis spp.), soy bean (Glycine max) and oilseed rape (Brassica napus L.) for biodiesel production. For this study we assumed that all first generation fuel was produced from these crops. Second generation biofuels are not currently produced commercially. To reduce the use of arable land to meet food production demands, second generation biofuels are predicted to increase and become the primary source of biofuel (International Energy Agency, 2010). We assume that all second generation biofuel was from lignocellulosic ethanol from short rotation coppice (SRC) crops such as wil- low (Salix spp.), poplar (Populus spp.) and eucalyptus (Eucalyptus spp.). The SRC crops are fast growing species harvested every $2-3 \mathrm{yr}$ for their biomass. Although biofuel feedstocks may not directly compete for arable land, e.g. some second generation crops may be grown on marginal or abandoned lands, there is concern that the effects of indirect landuse change as a result of their cultivation will impact negatively on food production and greenhouse gas emissions (Searchinger et al., 2008; Gallagher, 2008). Therefore, second generation fuel production from residues and wastes is also likely to be commercially developed to reduce these indirect LUC effects. These types of feed stock do not contribute to land-use change.

For each country included in PLUM, we estimate an additional area of cropland for biofuel cultivation, which was added to the change in cropland predicted by PLUM (summarized in Table 2). We considered biofuel production from sugarcane bioethanol, "other crop" bioethanol, "oilseed biodiesel" and SRC bioethanol. From biofuel scenario descriptions by the World Energy Outlook (International Energy Agency, 2009) and the International Energy Agency International Energy Agency (2010) we determined the percentage contribution of each biofuel category to the total predicted volume. For the "other crop" bioethanol and "oilseed" biodiesel biofuel categories, several crops were considered as feedstocks. We estimated the volume per biofuel class from the percentage contribution. Biofuel produced from residues are not considered in the total volume for the 450 scenario, as described above. We assumed that biofuel production was equally distributed between the selected crops for the "other crop" and "oilseed" biofuel classes. We estimated the area for future biofuel production. Biofuel yields were averaged for individual crops where different values were available for separate countries or regions.

We estimated the area of future biofuel crop cultivation per country by downscaling the IEA-derived global area of biofuel crop cultivation (Table 2) using nonlinear least squares fitting. We assume the predicted biofuel crop area per country was proportional to the area of crop (e.g. sugarcane) harvested in 2009 (http://faostat.fao.org/) and the area available for cultivation within individual countries. Hence, a country that produced more of a particular crop, and had a greater area of available land, would grow more of that crop for biofuel compared to a country that currently produces less and has less available land. We estimated the area necessary to support future biofuel crop cultivation for selected biofuel crops (sugarcane, maize, cassava, sugar beet, oil palm, rapeseed, soybean and SRC) on a per country basis, assuming future cultivation would only occur in countries already identified as producers by the FAO (http://faostat.fao.org/). The estimated area per crop was summed for each country and added to the LUC from PLUM to give a data set of total LUC per country. 
Table 2. Estimated total area required for biofuel production in the Reference and 450 scenarios.

\begin{tabular}{|c|c|c|c|c|c|c|}
\hline Scenario & Feed & & $\begin{array}{r}\text { Biofuel } \\
(\%)\end{array}$ & $\begin{array}{r}\text { Volume } \\
\text { (L) }\end{array}$ & $\begin{array}{c}\text { Yield }^{\mathrm{b}} \\
\left(\mathrm{Lha}^{-1}\right)\end{array}$ & $\begin{array}{l}\text { Area } \\
\left(\mathrm{m}^{2}\right)\end{array}$ \\
\hline \multirow[t]{8}{*}{ "Reference" } & $\mathrm{SC}$ & & 25 & $4.00 \times 10^{10}$ & 4900 & $8.16 \times 10^{10}$ \\
\hline & MA & \multirow{4}{*}{ "Other crop" } & \multirow{4}{*}{25} & \multirow{4}{*}{$4.00 \times 10^{10}$} & 4000 & \multirow{4}{*}{$1.64 \times 10^{11}$} \\
\hline & $\mathrm{CS}$ & & & & 2600 & \\
\hline & SB & & & & 1672 & \\
\hline & OP & & & & 3600 & \\
\hline & RS & \multirow[t]{3}{*}{ "Oilseed" } & \multirow{2}{*}{25} & \multirow{2}{*}{$4.00 \times 10^{10}$} & 1700 & \multirow{2}{*}{$3.06 \times 10^{11}$} \\
\hline & SY & & & & 700 & \\
\hline & SRC & & 25 & $4.00 \times 10^{10}$ & 3100 & $1.29 \times 10^{11}$ \\
\hline Total & & & 100 & $1.60 \times 10^{10}$ & & $6.81 \times 10^{11}$ \\
\hline \multirow[t]{8}{*}{ “450” } & $\mathrm{SC}$ & \multirow{5}{*}{ "Other crop" } & 40 & $1.15 \times 10^{10}$ & 4900 & $2.35 \times 10^{11}$ \\
\hline & MA & & \multirow{4}{*}{12} & \multirow{4}{*}{$3.49 \times 10^{10}$} & 4000 & \multirow{4}{*}{$1.43 \times 10^{11}$} \\
\hline & $\mathrm{CS}$ & & & & 2600 & \\
\hline & SB & & & & 1672 & \\
\hline & $\mathrm{OP}$ & & & & 3600 & \\
\hline & RS & \multirow[t]{3}{*}{ "Oilseed" } & 6 & $1.45 \times 10^{10}$ & 1700 & \multirow[t]{2}{*}{$1.33 \times 10^{11}$} \\
\hline & SY & & & & 700 & \\
\hline & $\mathrm{SRC}$ & & 41 & $1.24 \times 10^{11}$ & 3100 & $4.00 \times 10^{11}$ \\
\hline Total & & & 100 & $2.91 \times 10^{11}$ & & $9.12 \times 10^{11}$ \\
\hline
\end{tabular}

\subsection{Downscaling land-use changes from country to model grid scale}

The country-scale LUC data from PLUM were downscaled to a regular $0.5^{\circ}$ grid for each of the 162 countries described in PLUM using a similar approach described above for the biofuels. We used the spatially resolved plant functional type (PFT) database from MEGAN (Sect. 2.4) to identify existing areas of crop land. Crop area was assigned to individual $0.5^{\circ}$ grid cells based on the proportion of existing crop land to available land so that a greater area of crop land was assigned to grid cells which had a larger area of existing crop land and available land. We designated area covered by needleleaf tree, broadleaf tree and grass PFTs as available land. The shrub PFT generally covered marginal, less productive land that was less suitable for cropping so was not altered in this study. In most scenarios crop area expanded (Smith et al., 2010). We assigned a crop land area to each grid cell and an area equivalent to this was removed from the broadleaf tree, needleleaf tree and grassland PFTs, proportional to their coverage in that grid cell.

Uncertainty in land cover distribution, e.g. discrepancies between land cover data sets, was not explored as part of this study as the land cover data is regridded to $4^{\circ}$ latitude $\times 5^{\circ}$ longitude during the model run. At this resolution small-scale differences in global cropland distribution will not be resolved. In addition, the plant functional types (PFTs) defined in this study, both in PLUM and MEGAN/GEOS-Chem) are quite broad, limiting the resolution of cropland location. We acknowledge that using a higher resolution model run, which was too computationally expensive for our ensemble-based study, would allow for uncertainty in land cover distribution to be explored.

\subsection{The GEOS-Chem global 3-D chemistry transport model}

We use the GEOS-Chem global 3-D chemistry transport community model (version v9-01-02), driven by assimilated meteorology from the NASA Goddard Earth Observation System version 5 (GEOS-5) using a horizontal resolution of $4^{\circ}$ latitude $\times 5^{\circ}$ longitude, to quantify the impact of LUC on BVOC emissions and the subsequent changes in atmospheric oxidant chemistry. Here, we only include details of the model that are pertinent to the study; for further details the reader is encouraged to visit http://www.geos-chem.org and/or Bey et al. (2001).

BVOC emissions are taken from MEGAN v2.1 (Guenther et al., 2006). We assumed that where we increased cropland area for food production, or where we expanded forests and grasslands and decreased cropland area, existing local species (crops, forest or grass) would be planted and that the isoprene emission factors assigned to a particular grid cell would not change. Thus, as the proportional coverage of the PFTs changed within the grid cell, the weighting of the isoprene emission factors assigned to the PFTs changed, 
increasing or decreasing the total isoprene emission from that grid cell. However, we did assign specific isoprene emission factors where cropland was expanded for biofuel feed stock cultivation as we considered a limited number of species so that in some countries large areas were converted for the cultivation of these crops. Table 3 shows the specific isoprene emission factors we assigned to these biofuel crops.

The Olson land cover data set $\left(0.5^{\circ} \times 0.5^{\circ}\right)($ Olson, 1992), used by GEOS-Chem for the soil $\mathrm{NO}_{\mathrm{x}}$ emissions and dry deposition, was modified according to the land cover changes estimated for food and biofuel production in this study. Cropland area was expanded or contracted in the Olson grid cells according to where cropland area was changed in the MEGAN PFT data set (also on a $0.5^{\circ} \times 0.5^{\circ}$ grid). Any other land cover types within a crop-modified grid cell were correspondingly decreased, or increased, proportional to their coverage of that grid cell. Dry deposition was estimated using the scheme by Wesley (1989).

Emissions of $\mathrm{NO}_{\mathrm{x}}$ from soil sources were estimated using the scheme described by Wang et al. (1998). In this study the Olson land cover map was altered for each LUC realisation (see above) so that changes in $\mathrm{NO}_{\mathrm{x}}$ emissions from fertilizer application were accounted for as cropland area distribution changed. We assumed that the soil $\mathrm{NO}_{\mathrm{x}}$ emission rates for additional food and biofuel were the same as the application rates for the existing crops described by Yienger and Levy (1995). We have used specific $\mathrm{NO}_{\mathrm{x}}$ emission rates where they have been reported, e.g. oil palm cultivation (Hewitt et al., 2009). We modified the soil $\mathrm{NO}_{\mathrm{x}}$ emissions within the standard version of GEOS-Chem (Yienger and Levy, 1995) to account for $\mathrm{NO}_{\mathrm{x}}$ emissions from fertiliser application and processing of the oil palm fruit to biodiesel. Additional NO Emissions of $3.4 \mathrm{~kg} \mathrm{ha}^{-1} \mathrm{yr}^{-1}$ (Ashworth et al., 2012) were assumed to be colocated with the expanded oil palm cultivation for biofuel production. We used the GEOS-Chem model to quantify the impact of LUC on the isoprene emissions (IQR of PLUM ensemble) and the subsequent oxidant chemistry (for the IQR statistics of the emissions for each combined IPCC/biofuel scenario). In this study we quantify how LUC due to increased food and biofuel production will perturb isoprene emissions and surface ozone and do not consider future climate and meteorology. We use meteorology from 2004. For the oxidant chemistry we ran the model for a year following a two-year spin-up period for 2004 to remove initial conditions. We ran a total of 24 experiments that correspond to two IPCC AR4/SRES scenarios (A1 and B1), two biofuel scenarios (Reference and 450), two years (2015, 2030), and the median and IQR of the statistics.
Table 3. Isoprene emission factors assumed for biofuel crops in this study.

\begin{tabular}{|c|c|c|}
\hline \multicolumn{2}{|l|}{ Crop } & $\begin{array}{l}\text { Emission Factor } \\
\qquad\left(\mu \mathrm{g} \mathrm{m}^{-2} \mathrm{~h}^{-1}\right)\end{array}$ \\
\hline \multicolumn{2}{|l|}{ Sugarcane } & 0.0 \\
\hline \multicolumn{2}{|l|}{ Maize } & 0.0 \\
\hline \multicolumn{2}{|l|}{ Cassava } & 0.0 \\
\hline \multicolumn{2}{|l|}{ Sugar beet } & 0.0 \\
\hline \multicolumn{2}{|l|}{ Oil Palm ${ }^{\mathrm{a}}$} & 7800 \\
\hline \multicolumn{2}{|l|}{ Rapeseed } & 0.0 \\
\hline \multicolumn{2}{|l|}{ Soybean ${ }^{b}$} & 18.5 \\
\hline \multicolumn{3}{|c|}{ Short rotation coppice ${ }^{c}$ : } \\
\hline \multicolumn{3}{|c|}{ Eucalyptus | } \\
\hline $\begin{array}{l}\text { Poplar } \\
\text { Willow }\end{array}$ & Average & $4.81 \times 10^{4}$ \\
\hline
\end{tabular}

a Misztal et al. (2011); ${ }^{\mathrm{b}}$ Available from

http://bai.acd.ucar.edu/Data/BVOC/index.shtml; ${ }^{c}$ Average

isoprene emission factor for Eucalytus, Poplar and Willow

from Simpson et al. (1999) and

http://bai.acd.ucar.edu/Data/BVOC/index.shtml

\section{Results}

\subsection{PLUM land-use change ensembles for A1 and B1 scenarios}

The PLUM model was used to generate 1000 LUC realizations each for the A1 and B1 scenarios. Figure 2 shows the change in global cropland and forest + grassland area across both ensembles, A1 and B1, from 1990-2050. We found that LUC in the PLUM model was strongly influenced by technological development which determined the rate of increase in crop yield (Baumanns et al., 2013). For example if the rate of increase in crop yield was lower, the increase in global cropland area and corresponding decrease in forest and grass land area was greater, i.e. more cropland was required for food production when crop yields (per unit area) were lower (and vice versa).

Table 4 summarizes the change in global cropland area between 1990 and 2015 and between 2015 and 2030; the global cropland area in 1990 was $7.34 \times 10^{12} \mathrm{~m}^{2}$ (http://faostat.fao. org/). Changes in global cropland discussed in this section are relative to 1990 . In the A1 scenario, global cropland generally decreased until $\approx 2020$, after which time global cropland increased (Fig. 2a). In 2015 global cropland area changed between $-13 \%$ to $+47 \%$, with the median realization resulting in a small decrease of $-3 \%$. By 2030 the change in global cropland area ranged between $-20 \%$ to $+82 \%$, with the median realization resulting in an increase of $+6 \%$. The overall positive trend in global cropland area by 2030 in the A1 scenario is a result of increasing global population and average GDP combined with increasing rates of meat and milk consumption. This expansion is offset to a certain extent by high rates of technological development 
Table 4. Summary of change in global cropland area from 1990 to 2015 and from 2015 to 2030. For each IPCC AR4/SRES scenario the PLUM realizations corresponding to the median, maximum and minimum difference in global cropland area are shown. Changes in global cropland are discussed relative to 1990 .

\begin{tabular}{clccc}
\hline Year & Scenario & Median LUC m ${ }^{2}(\%)$ & $\operatorname{Max~LUC~m}^{2}(\%)$ & $\operatorname{Min} \operatorname{LUC~m}^{2}(\%)$ \\
\hline 2015 & A1 & $-0.19 \times 10^{12}(-3)$ & $3.42 \times 10^{12}(47)$ & $-0.98 \times 10^{12}(-13)$ \\
& B1 & $-0.22 \times 10^{12}(-3)$ & $1.74 \times 10^{12}(24)$ & $-0.71 \times 10^{12}(-10)$ \\
2030 & A1 & $0.45 \times 10^{12}(6)$ & $6.06 \times 10^{12}(82)$ & $-1.50 \times 10^{12}(-20)$ \\
& B1 & $-0.39 \times 10^{12}(-5)$ & $2.99 \times 10^{12}(41)$ & $-1.12 \times 10^{12}(-15)$ \\
\hline
\end{tabular}

that result in better crop yields. In contrast, global cropland area generally decreased in the B1 scenario ensemble. In 2015 and 2030, the median realizations resulted in decreases of $-3 \%$ and $-5 \%$, respectively. In the B1 scenario the rates of meat and milk consumption decreased, which combined with lower rates of land abandonment and deforestation, lead to an overall decrease in global cropland area. The greater divergence in change in global cropland area between realizations in the $\mathrm{A} 1$ ensemble compared with the B1 ensemble reflects the greater rates of increase in meat consumption, milk consumption and land abandonment in the A1 scenario. In comparison, estimates of future cropland area (for 2030) derived from several integrated assessment models (IPCC/SRES, 2000, Appendix VII), ranged from $-0.3 \%$ to $+50 \%$ for the A1 scenario (mean change $=+11.5 \%$ ) and from $-6.5 \%$ to $+24.7 \%$ for the B1 scenario (mean change $=+4.7 \%$ ). The greater spread across the PLUM estimates reflects the ability of this modelling approach to explore a diverse range of futures within a single modelling framework.

Figure 3 shows the simulated net changes in cropland area per country for the median realizations of the A1 and B1 scenarios in 2030, downscaled to a $0.5^{\circ} \times 0.5^{\circ}$ grid (Sect. 2.3) . Cropland expansion estimated for the 450 and Reference biofuel scenarios is included. The spatial distribution of changes in cropland area was similar in the median realizations shown here, mainly driven by similarities in the rates of change in population, but the magnitude of these changes was dependent on the IPCC AR4/SRES and biofuel scenarios. The largest and most extensive increases in cropland were estimated for the median A1/450 combination (Fig. 3a), reflecting the greater increases in cropland area simulated by PLUM for the A1 scenario and estimated for the 450 biofuel scenario. In contrast, less cropland expansion was simulated in the B1 scenario and Reference biofuel scenario and consequently the smallest increases in cropland and most extensive decreases in cropland were estimated for the median B1/Reference combination (Fig. 3d).

The most prominent increases in cropland area were observed in Brazil, tropical South America and sub-Saharan African countries. Smaller increases were observed in North America and Canada, Southeast (SE) Asia and southwestern (SW) Russia. In sub-Saharan Africa, tropical South America, Canada and SE Asia cropland area expansion was primar-

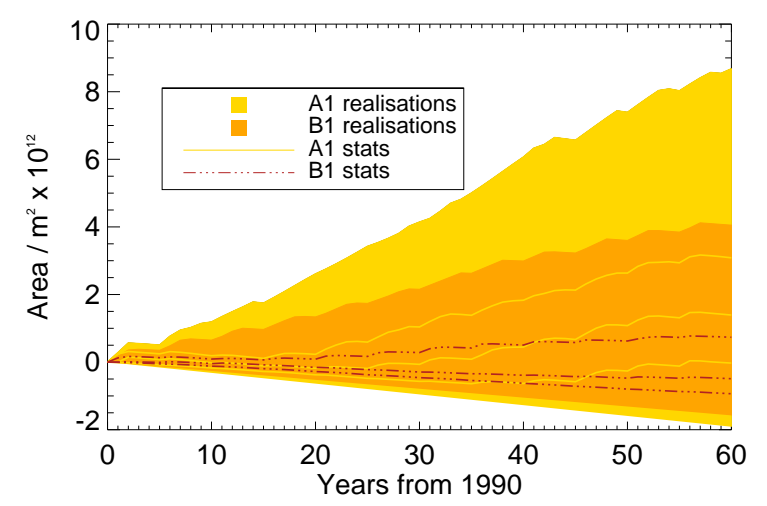

(a) Change in global crop land

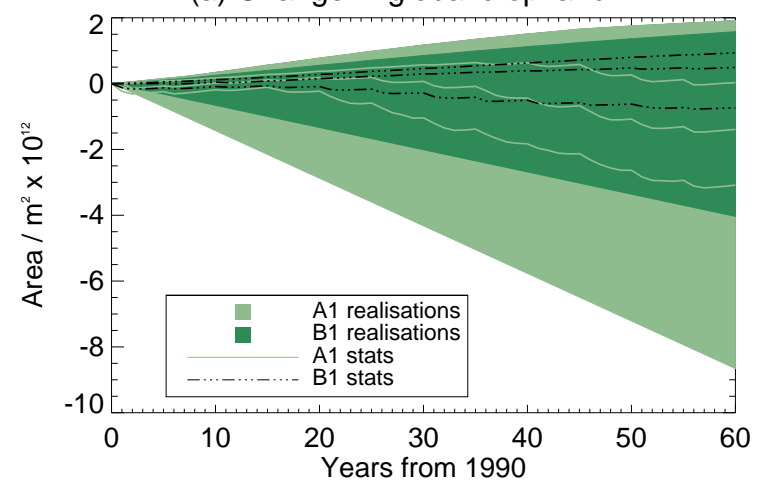

(b) Change in global forest+grass land

Fig. 2. Ensemble ( $n=1000)$ change in (top) total global cropland $\left(10^{12} \mathrm{~m}^{2}\right)$ from 1990 to 2050 (bottom) global forest + grassland $\left(10^{12} \mathrm{~m}^{2}\right)$ for A1 and B1 SRES scenarios (Table 1). The "stats" lines denote the median, upper and lower quartiles for each ensemble.

ily driven by increased food production simulated by PLUM, whereas in Brazil, SW Russia and North America cropland area expansion for biofuel cultivation was also important. The net decreases in cropland area over Western Europe, India and northwest China (Fig. 3) were driven by decreases in cropland predicted by PLUM.

The methods used for distributing area for biofuel cultivation resulted in large increases in cropland in countries where there was a large area of existing biofuel crop and a large available area. Consequently, there are large increases 


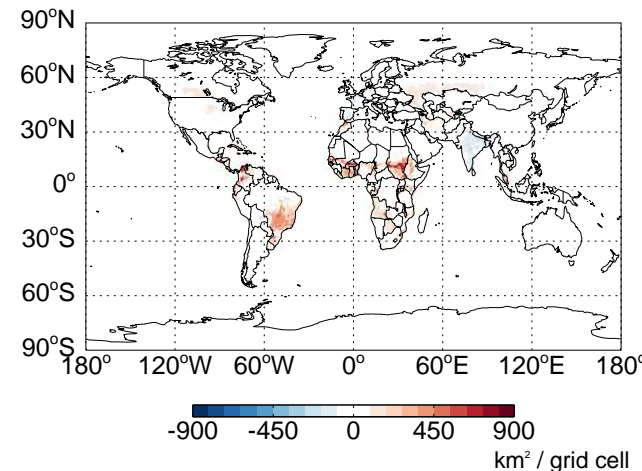

(a) $\mathrm{A} 1 / 450$

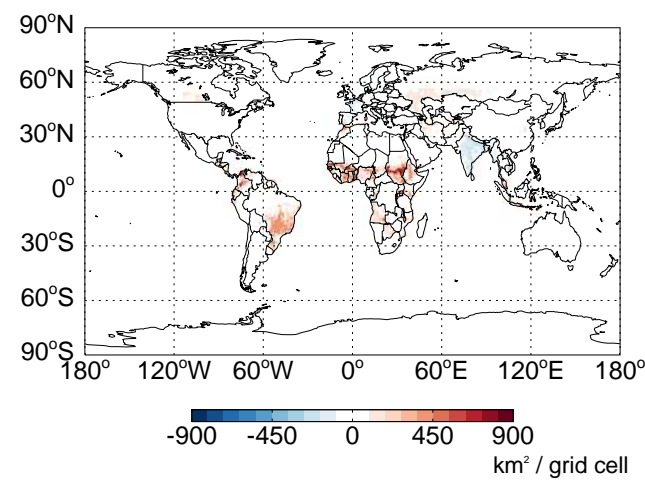

(c) $A 1 /$ Ref

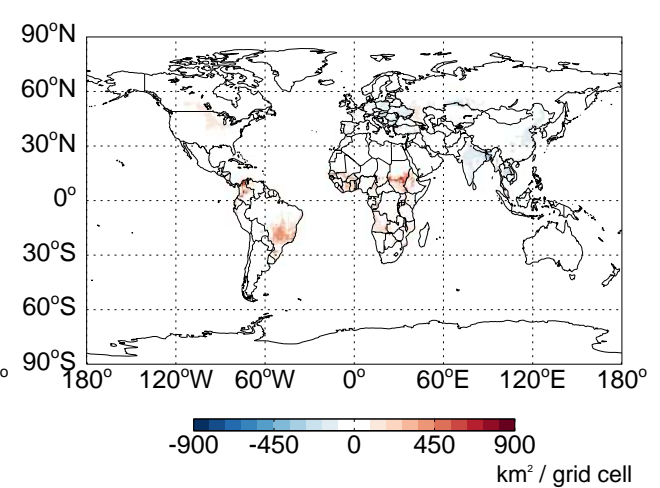

(b) $B 1 / 450$

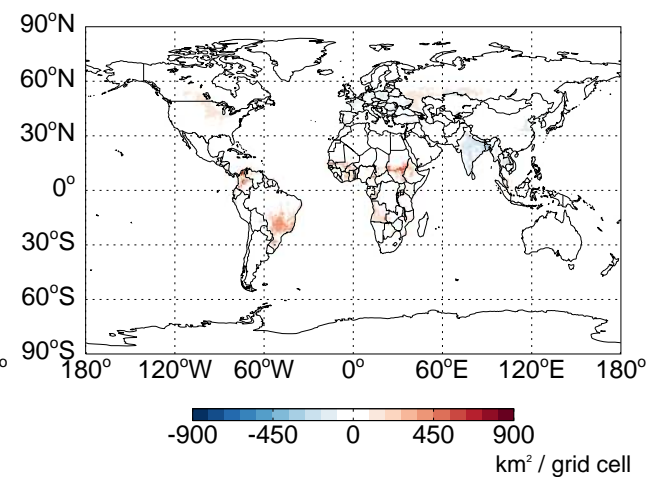

(d) B1/Ref

Fig. 3. Median of the spatial distribution of changes in cropland area $\left(\mathrm{km}^{2}\right.$ gridcell $\left.{ }^{-1}\right)$ for the ensemble of A1 and B1 LUC scenarios estimated by PLUM, including the 450 and Reference biofuel usage scenarios $(n=1000)$ in 2030. Country scale changes are downscaled to a $0.5^{\circ} \times 0.5^{\circ}$ grid using a method detailed in the main text.

in sugarcane and soybean cultivation in Brazil, which are more extensive in the 450 scenario compared with the Reference scenario (comparing Fig. 3a with $\mathrm{c}$ and Fig. $3 \mathrm{~b}$ with d). SRC crops, which are not currently produced commercially, were distributed globally with the result that they were primarily located in North America, Russia and China; countries with large areas of available land. Cropland expansion for SRC crop cultivation was greater in the 450 scenario where it comprised $\approx 45 \%$ of the total biofuel area (Table 2 ). In China and North America the large expansion of SRC crop was offset by decreases in cropland for food production such that no net LUC was observed in China in the 450 scenario and net decreases were observed in the Reference scenario.

\subsection{Impact of LUC estimates on global isoprene emissions}

Figure 4 shows monthly global isoprene emissions $\left(\right.$ Tg month ${ }^{-1}$ ) from the "emissions only" GEOS-Chem runs for the A1 and B1 scenarios in 2015 and 2030. In addition to the control calculation (zero LUC, hereinafter known as ZLUC), we report the median (Med), bottomof-the-range (BoR), and top-of-the-range (ToR) values in the ensemble for the 450 and Reference biofuel scenar- ios. For each ensemble (A1/450, A1/Reference, B1/450, B1/Reference) there were $n=500$ realizations. In 2015 the global isoprene burden increased by a maximum of $+2.8 \mathrm{Tg}(0.61 \%)$ and decreased by a maximum of $-3.5 \mathrm{Tg}$ $(0.76 \%)$ in the $\mathrm{A} 1 / 450 / \mathrm{ToR}$ and $\mathrm{A} 1 / \mathrm{Ref} / \mathrm{BoR}$ realizations, respectively. By 2030 the change in the global isoprene burden ranged from $+6.4 \mathrm{Tg}(1.40 \%)$ to $-7.7 \mathrm{Tg}(1.67 \%)$ in the A1/450/ToR and A1/Ref/BoR realizations, respectively. The greater range of values in 2030, within and across the A1 and B1 scenarios, reflects increased divergence between the realizations through time and high rates of increase in consumption for A1 compared with B1 (Sect. 3.1). The changes in global isoprene burden in 2030 are similar in magnitude to results from previous work by Wu et al. (2012) that included the compound effects of climate change and LUC for 2050 and Ashworth et al. (2012) where LUC for biofuel cultivation only was reported, but smaller than the $12 \%$ decrease reported by Ganzeveld et al. (2010) for 2050. However, the changes of $\pm 6-8 \mathrm{Tg} \mathrm{yr}^{-1}$ reported here are very small compared to uncertainty in the global isoprene budget which is estimated to be between $402-660 \mathrm{Tg} \mathrm{yr}^{-1}$ (Lathiere et al., 2010).

In our study, increases in the global isoprene burden were driven by elevated isoprene emissions during the Northern 


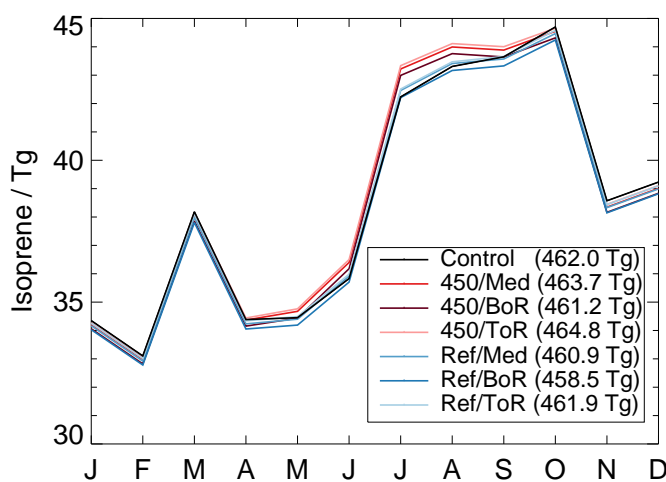

(a) A1: 2015

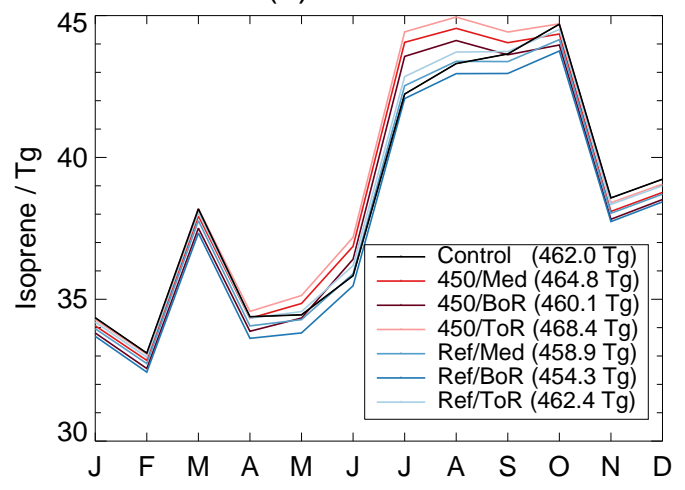

(c) A1:2030

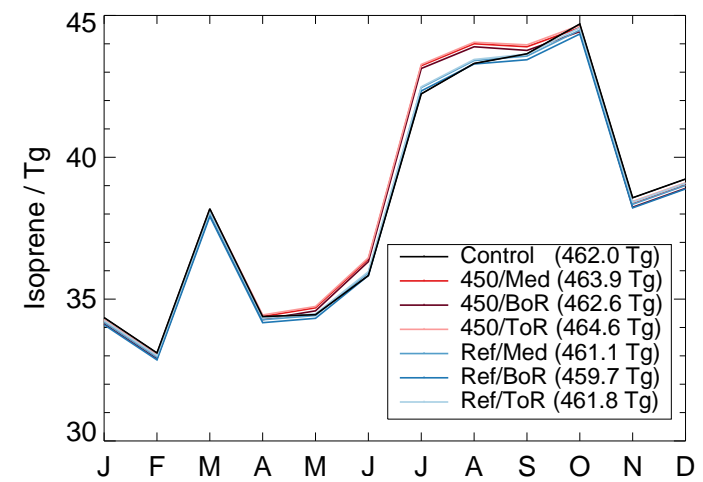

(b) B1:2015

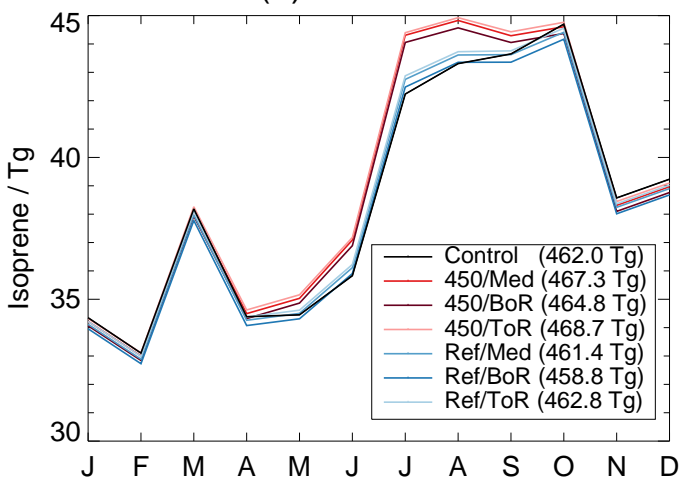

(d) B1:2030

Fig. 4. Monthly isoprene emissions (Tg month ${ }^{-1}$ ) for realizations corresponding to the median, top-of-the-range (ToR) and bottom-of-therange (BoR) in 2015 for A1 (a) and B1 (b) and in 2030 for A1 (c) and B1 (d). The 450 biofuel scenarios are shown in red and the Reference scenarios are shown in blue. The ZLUC scenario is shown in black.

Hemisphere summer as a result of adding large areas of strongly isoprene-emitting SRC crops for biofuel cultivation in the 450 scenario, particularly in North America, southwest Russia and northeast China. The summertime emissions increased from 2015 to 2030 as a result of doubling the total biofuel area. Outside of the Northern Hemisphere summer, the monthly isoprene emissions were reduced compared to the ZLUC scenario, which was a result of replacing the more strongly isoprene emitting forest and grassland PFTs, particularly in Brazil and sub-Saharan African countries, with less strongly emitting crop PFTs. Less SRC crop was inserted in the Reference scenario and the global isoprene burden generally decreased in these scenarios.

\subsection{Impact of LUC estimates on atmospheric oxidant chemistry}

We used the GEOS-Chem model to investigate the impact of LUC estimates on surface oxidant chemistry. We ran a total of 24 experiments, corresponding to the IQR statistics from the ensemble of A1/B1 scenarios, two biofuel scenarios (450 and Reference) for two years $(2015,2030)$. Figure 5 shows global and regional surface concentrations of isoprene, $\mathrm{O}_{\mathrm{x}}$
$\left(\mathrm{O}_{3}+\mathrm{NO}_{2}+2 \mathrm{NO}_{3}\right), \mathrm{NO}_{\mathrm{x}}\left(\mathrm{NO}+\mathrm{NO}_{2}\right)$, and $\mathrm{O}_{3}$ dry deposition flux for the contrasting months January and July.

The model calculations for 2015 and 2030 represent shortand medium-term projections of LUC. As previously discussed, changes in cropland from food and biofuel production were generally smaller in 2015 compared with 2030 (Fig. 2), resulting in smaller changes to the surface tracer composition (Figs. 4, 7-11). There was also less divergence between the LUC realizations in 2015 so that the range of the changes in surface oxidants is smaller compared with 2030. The annual global value was not significantly altered ( $<1 \mathrm{ppb}$ for isoprene and $\mathrm{O}_{\mathrm{x}}$ and $<0.001 \mathrm{ppb}$ for $\mathrm{NO}_{\mathrm{x}}$ ), but we found large regional changes.

In regions where LUC was driven by an increase in SRC crop cultivation for biofuel usage, e.g. China (Fig. 12), temperate North America (Fig. 13), and Russia (Fig. 14), the increase in surface isoprene concentrations, relative to ZLUC, during the Northern Hemisphere summer in 2030 was approximately double the increase in 2015 . This was a direct result of the two-fold increase in the area estimated for biofuel cultivation. This LUC led to a doubling of surface $\mathrm{O}_{\mathrm{x}}$ from 2015 to 2030. In regions where LUC was driven by crop expansion for food and biofuel production, e.g. Brazil, 

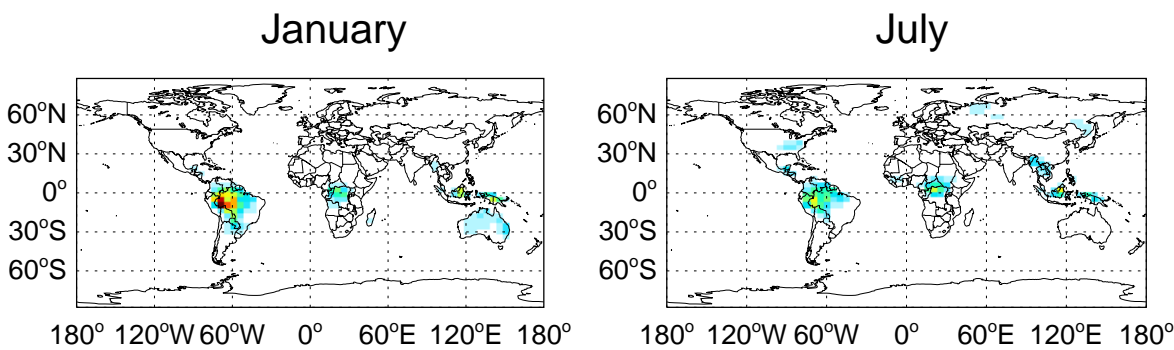

(a)

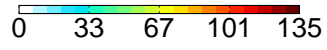

(b)
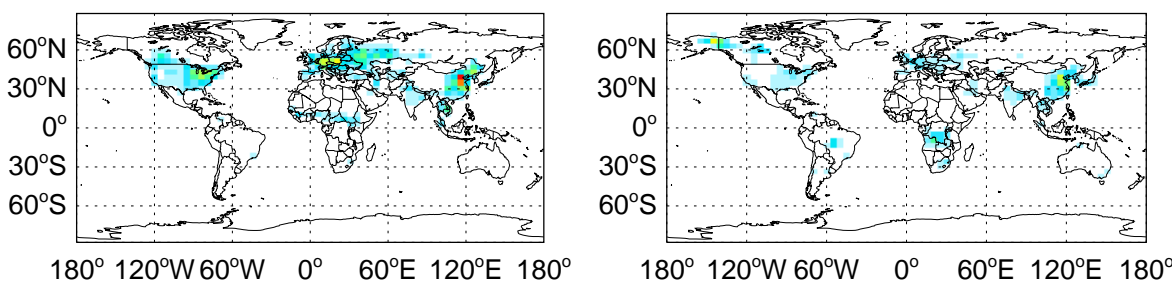

(c)

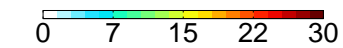

(d)
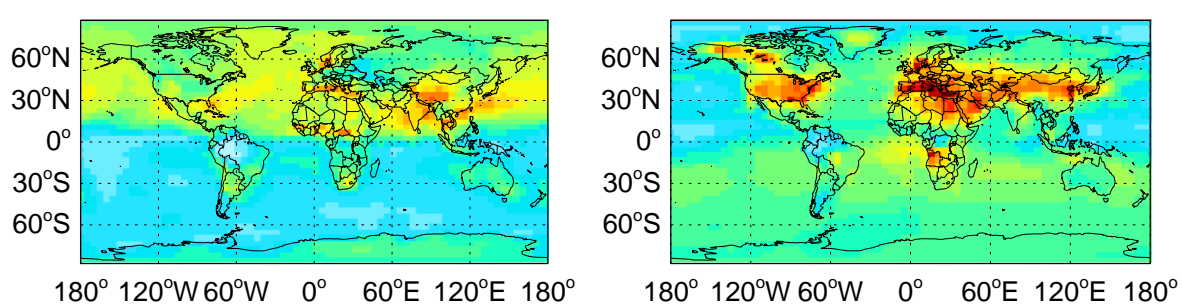

(e)

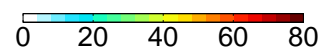

(f)
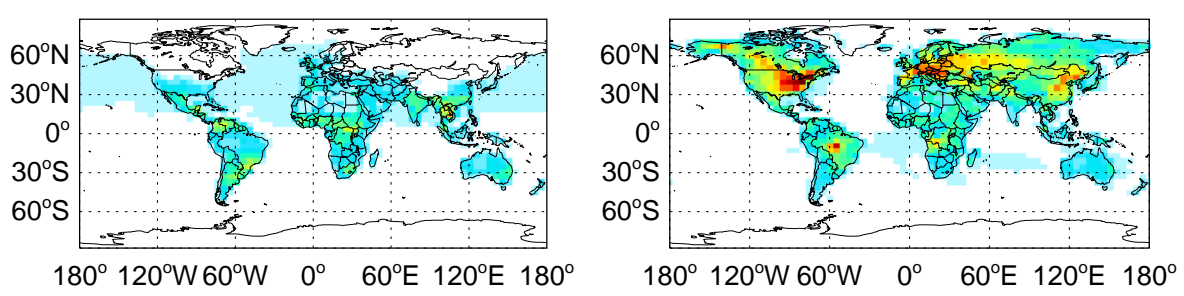

(g)

$0 . 0 0 \longdiv { \mathrm { e } + 0 0 } \quad 3 . 7 5 \mathrm { e } + 1 1 \quad 7 . 5 0 \mathrm { e } + 1 1$

(h)

$0.00 \mathrm{e+00} \quad 3.75 \mathrm{e}+11 \quad 7.50 \mathrm{e}+11$

Fig. 5. Surface concentrations of isoprene in ppb, (a) and (b); $\mathrm{NO}_{\mathrm{x}}$ in ppb (c) and (d); $\mathrm{O}_{\mathrm{x}}$ in ppb (e) and (f) and $\mathrm{O}_{3}$ surface flux in molecules $\mathrm{cm}^{-2} \mathrm{~s}^{-1}$ (g) and (h) for ZLUC calculation. Plots for January and July and shown in the left and right panels, respectively.

southern Africa, tropical South America, we saw a decrease in surface isoprene and corresponding increases in surface $\mathrm{O}_{\mathrm{x}}$ that was greater in 2030 than in 2015 . The change in surface $\mathrm{NO}_{\mathrm{x}}$ is dependent on land cover change: if forest area increases (decreases) less (more) $\mathrm{NO}_{\mathrm{x}}$ escapes to the atmosphere (Wang et al., 1998). We saw larger changes in 2030 than in 2015.

In this study we found that surface $\mathrm{O}_{3}$ fluxes increased where cropland area was expanded (either for food production or biofuel cultivation), e.g. in Brazil, tropical South America, southern Africa, temperate North America and bo- real Eurasia, but decreased where cropland was reduced, e.g. in Europe, India and China. Note that in this study a positive flux represents emission to the atmosphere, whereas a negative flux represents dry deposition. The increasing fluxes in areas where cropland was expanded were driven by reduced leaf area indices (LAIs) and surface roughness, particularly compared with forest PFTs. The changes in dry deposition fluxes, whether an increase or decrease relative to ZLUC, were greater in 2030 compared with 2015.

We report on eight geographical regions, loosely based on TransCom definitions (Gurney et al., 2002) (Fig. 6) over 


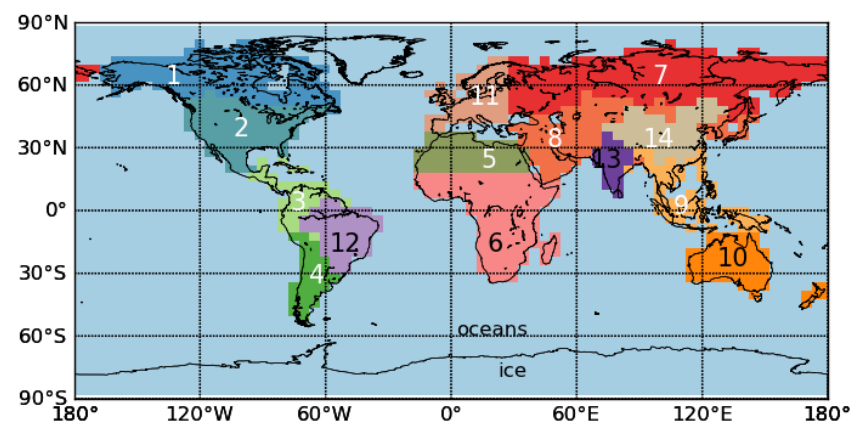

Fig. 6. Geographic regions used in this study: $1=$ boreal North America, $2=$ temperate North America, $3=$ tropical South America, $4=$ temperate South America, $5=$ North Africa, $6=$ southern Africa, $7=$ boreal Eurasia, $8=$ temperate Eurasia, $9=$ tropical Asia, $10=$ Australasia, $11=$ Europe, $12=$ Brazil, $13=$ India, $14=$ China.

which we saw the largest changes in atmospheric composition due to LUC: (1) Brazil, (2) tropical South America, (3) China, (4) India, (5) Western Europe, (6) Russia, (7) temperate North America and (8) sub-Saharan, Central and southern African combined in a single region (denoted "southern Africa"). These regions encompass the areas in which the greatest LUC resulting from changes in food production and biofuel cultivation were located, (Fig. 3). Figures 7-14 show the average surface change in tracer composition across the selected region relative to ZLUC and changes in surface tracer composition are reported below relative to ZLUC. For each scenario the box and whiskers represents the range of the changes in surface tracer composition across the selected scenarios in 2030 and 2015.

\subsubsection{Southern Africa, Brazil and tropical South America}

Figure 3 shows that cropland area for food production expands widely across southern Africa, Brazil and tropical South America in many of the realizations in the LUC scenarios. Cropland area also expands for biofuel cultivation in southern Africa and Brazil, but little expansion of these crops was simulated in tropical South America due to relatively small areas of existing biofuel crop area and available cropland area in the relevant countries.

The conversion from more highly isoprene emitting forest (generally broadleaf tree in these regions) and grassland PFTs to low isoprene emitting cropland PFTs generally resulted in a reduction of the surface isoprene mixing ratios relative to ZLUC by up to $-0.5 \mathrm{ppb},-1.8 \mathrm{ppb}$ and $-1.1 \mathrm{ppb}$ in southern Africa (Fig. 7a), Brazil (Fig. 8a) and tropical South America (Fig. 9a), respectively, in 2030. The greatest decreases in isoprene and associated changes in surface oxidant chemistry (as discussed below) occurred in the A1 scenario reflecting the higher demand for cropland compared with the B1 scenario. In Brazil, and to a lesser extent south- ern Africa where cropland also expanded for biofuel cultivation, greater changes in surface oxidant chemistry occurred in the 450 scenario. Surface isoprene and $\mathrm{O}_{\mathrm{x}}$ mixing ratios in these two regions varied by $\approx+0.4 \mathrm{ppb}$ and $\approx+0.2-0.3 \mathrm{ppb}$ across the 24 LUC experiments. In tropical South America where little biofuel cultivation was simulated and cropland area for food production expanded to a similar degree in the $\mathrm{A} 1$ and $\mathrm{B} 1$ scenarios, surface isoprene and $\mathrm{O}_{\mathrm{x}}$ mixing ratios across the 24 LUC experiment only varied by $\approx+0.2 \mathrm{ppb}$ and $\approx+0.1 \mathrm{ppb}$, respectively.

The changes in surface oxidant chemistry were strongly dependant on the seasonal cycles of each region. The greatest decreases in surface isoprene mixing ratios tended to occur during regional wet seasons when isoprene emissions from forest and savannah (grassland) would normally peak. These occur from approximately July-September (peak wet season, monsoon) in western Africa and southern Sudan, November-April in Brazil and from April-October in tropical South America. In all three regions the decreases in surface isoprene mixing ratios, combined with low ambient $\mathrm{NO}_{\mathrm{x}}$ conditions, tended to give elevated surface $\mathrm{O}_{\mathrm{x}}$ mixing ratios of $\sim 0.1-0.3 \mathrm{ppb}$ above ZLUC in 2030, with the maximum increases occurring in conjunction with the maximum decreases in surface isoprene (Figs. 7c, 8c and 9c). The peak in surface $\mathrm{O}_{\mathrm{x}}$ observed in March/April in southern Africa (Figs. 7c) may have occurred in conjunction with peak surface $\mathrm{NO}_{\mathrm{x}}$ mixing ratios which occurred with soil re-wetting (Yienger and Levy, 1995) as rainfall began to increase at this time in eastern and western Africa (including southern Sudan).

The reduction in LAI through deforestation and grassland conversion resulted in greater release of soil $\mathrm{NO}_{\mathrm{x}}$ to the atmosphere, slightly increasing the surface $\mathrm{NO}_{\mathrm{x}}$ mixing ratios relative to ZLUC (Figs. 7b, 8b and 9b). Further, the reduction in LAI together with reduced surface roughness also increased $\mathrm{O}_{3}$ fluxes relative to ZLUC (Figs. 7d, 8d and 9d). The similarities in the seasonal trends between the changes in surface $\mathrm{O}_{x}$ mixing ratios and surface $\mathrm{O}_{3}$ flux suggests that in addition to reduced LAI and surface roughness, the increases in $\mathrm{O}_{\mathrm{x}}$ may also contribute to the increases in surface $\mathrm{O}_{3}$.

\subsubsection{India and Europe}

Cropland area for food production in India, Europe (and China) generally reduced in the PLUM LUC realizations as global demand (for food production) was met by increasing production in regions such as southern Africa (Baumanns et al., 2013). The PLUM model allows poor countries to increase their cereal production despite a positive world cereal balance. Rich countries do not, therefore, need to produce.

Figures 10a, and 11a show that, in contrast to the effects of LUC in Brazil, tropical South America and southern Africa, afforestation and increasing grassland area resulted in higher surface isoprene concentrations in India and Europe as the 


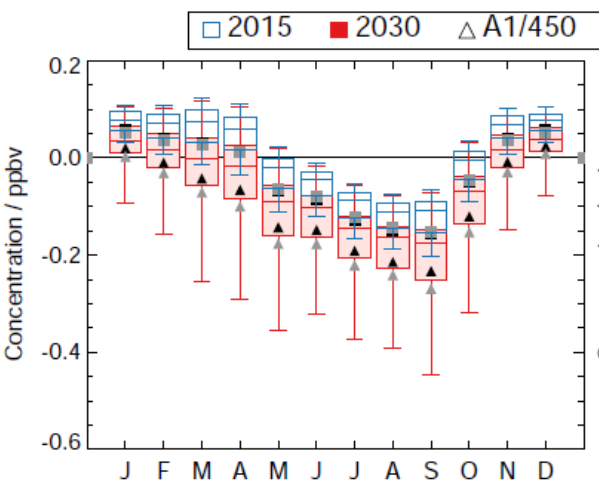

(a) Ave. change in surface ISOP conc.

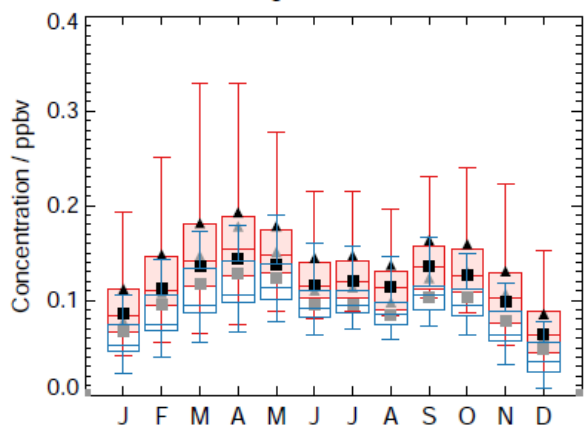

(c) Ave. change in surface $\mathrm{O}_{x}$ conc.

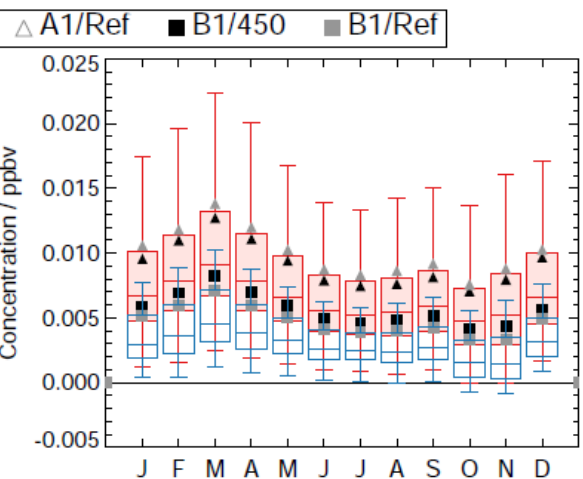

(b) Ave. change in surface $\mathrm{NO}_{x}$ conc.

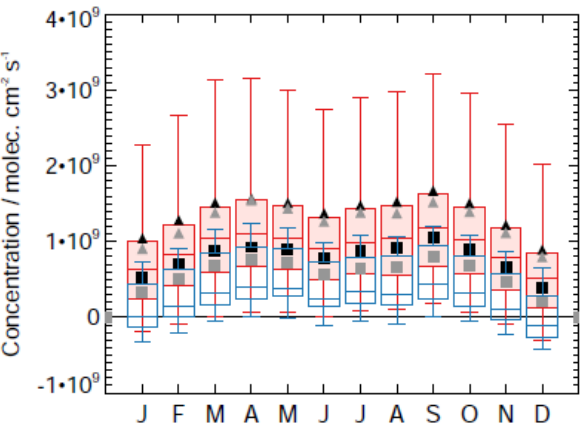

(d) Ave. change in surface $\mathrm{O}_{3} \mathrm{df}$

Fig. 7. Monthly mean statistics, expressed using box and whisker plots, for the change in isoprene (ppb), $\mathrm{NO}_{\mathrm{x}}(\mathrm{ppb})$, and $\mathrm{O}_{\mathrm{x}}(\mathrm{ppb}) \mathrm{surface}$ concentrations and $\mathrm{O}_{3}$ dry deposition (molecules $\mathrm{cm}^{-2} \mathrm{~s}^{-1}$ ) over Africa (Fig. 6) for 2015 and 2030.

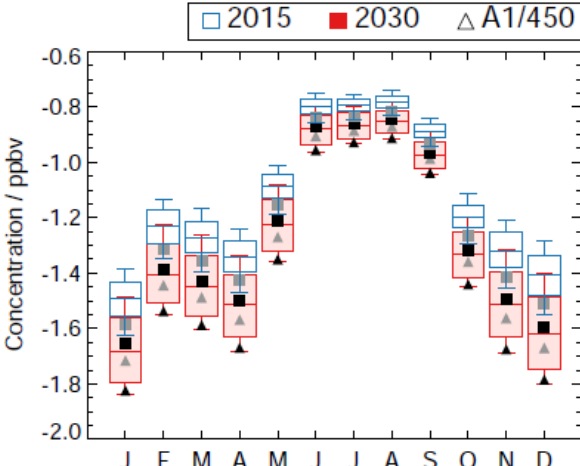

(a) Ave. change in surface ISOP conc.

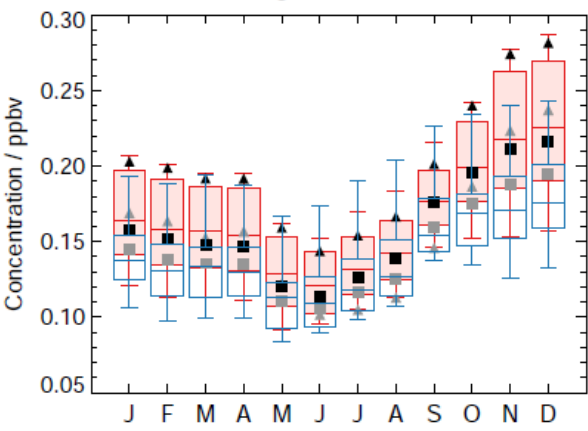

(c) Ave. change in surface $\mathrm{O}_{\mathrm{x}}$ conc.

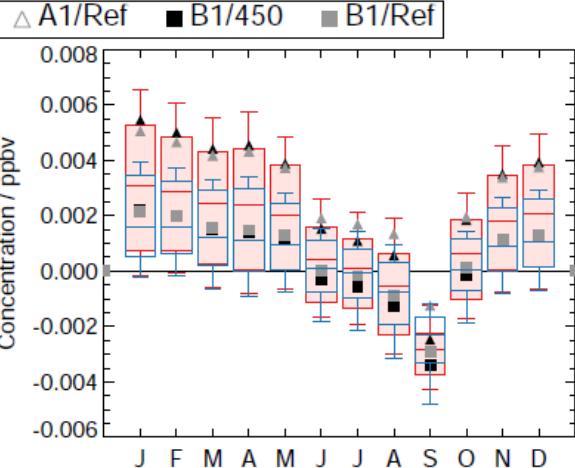

(b) Ave. change in surface $\mathrm{NO}_{x}$ conc.

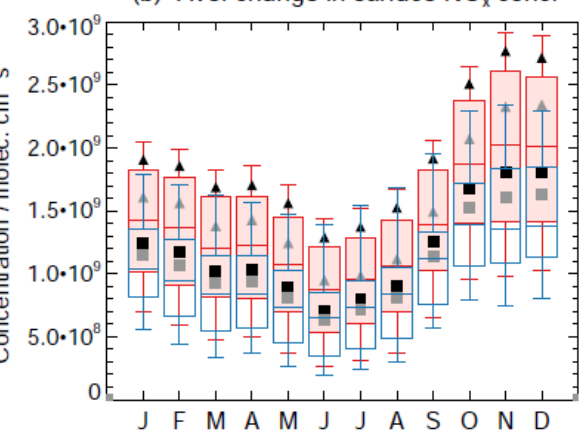

(d) Ave. change in surface $\mathrm{O}_{3} \mathrm{df}$

Fig. 8. Same as Fig. 7 but for Brazil (Fig. 6). 

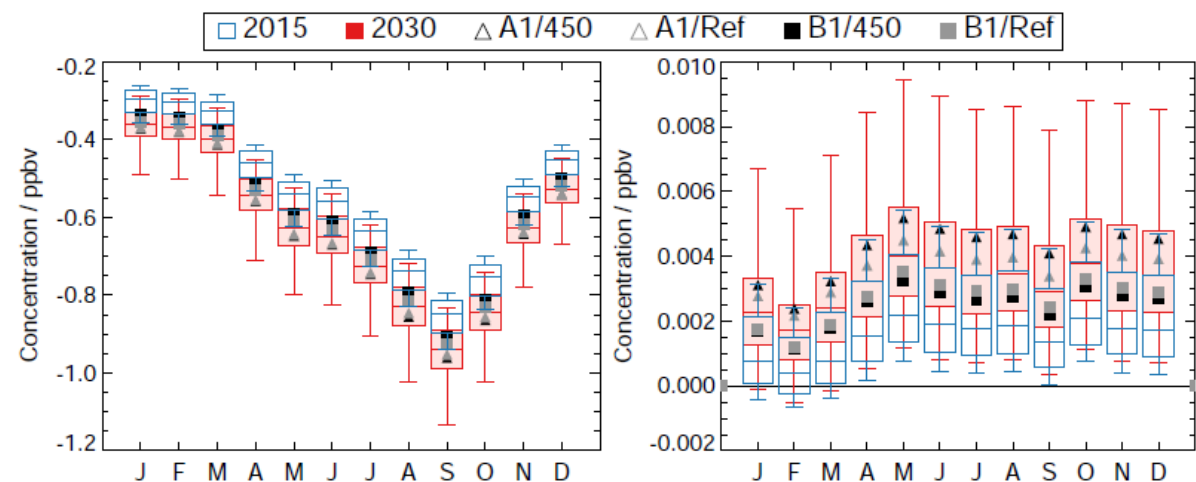

(a) Ave. change in surface ISOP conc.

(b) Ave. change in surface $\mathrm{NO}_{x}$ conc.

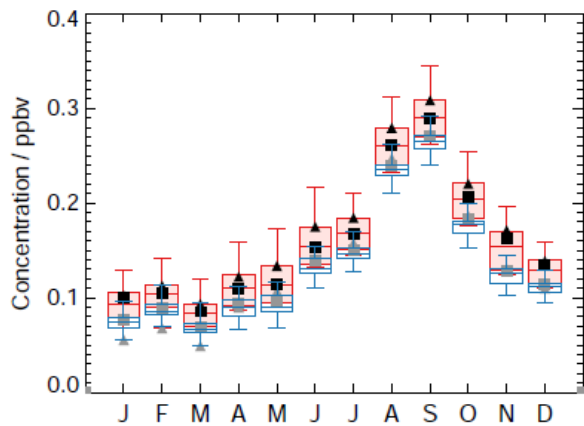

(c) Ave. change in surface $\mathrm{O}_{x}$ conc.

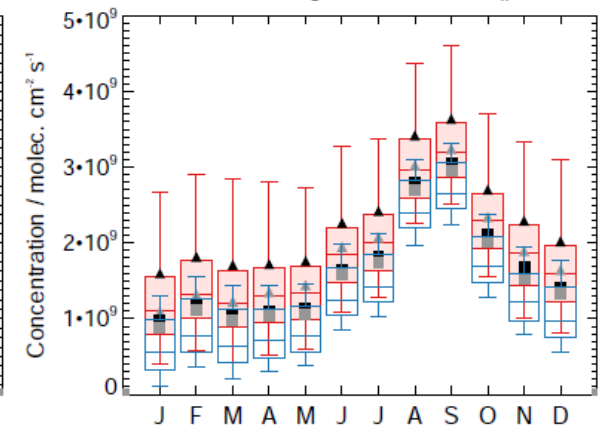

(d) Ave. change in surface $\mathrm{O}_{3} \mathrm{df}$

Fig. 9. Same as Fig. 7 but for tropical South America (Fig. 6).

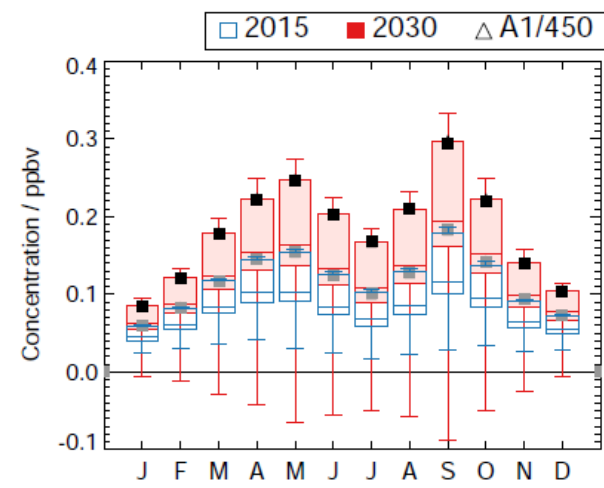

(a) Ave. change in surface ISOP conc.

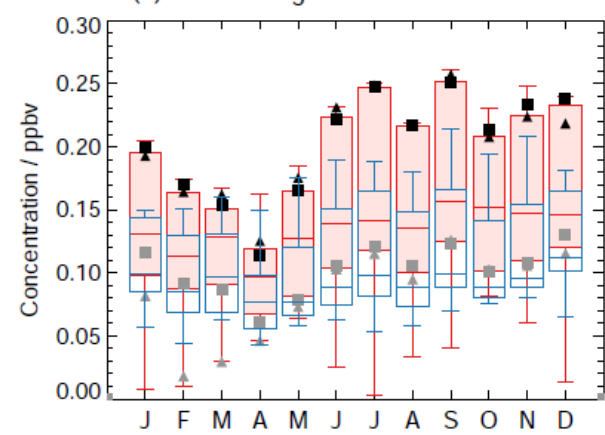

(c) Ave. change in surface $\mathrm{O}_{x}$ conc.

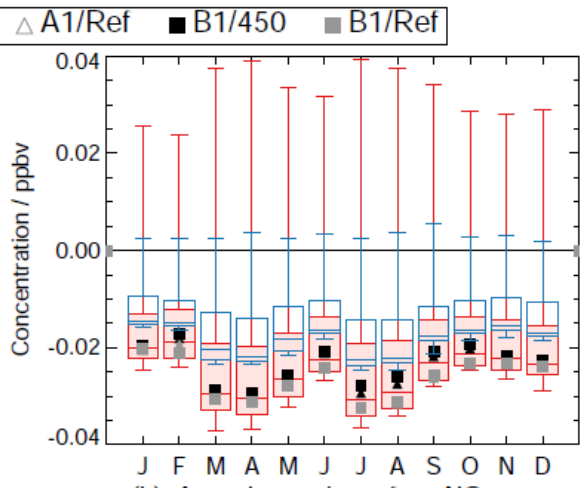

(b) Ave. change in surface $\mathrm{NO}_{x}$ conc.

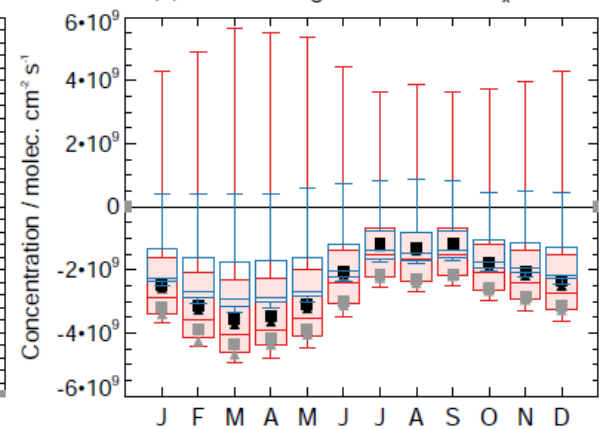

(d) Ave. change in surface $\mathrm{O}_{3} \mathrm{df}$

Fig. 10. Same as Fig. 7 but for India (Fig. 6). 


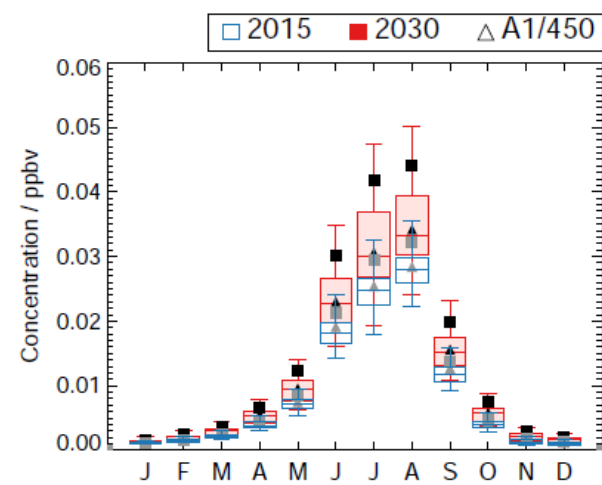

(a) Ave. change in surface ISOP conc.

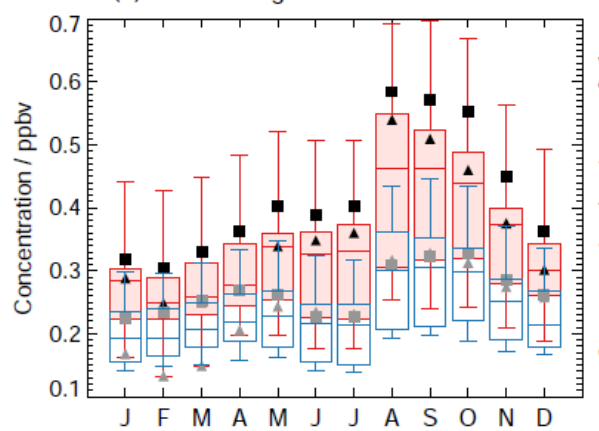

(c) Ave. change in surface $\mathrm{O}_{x}$ conc.

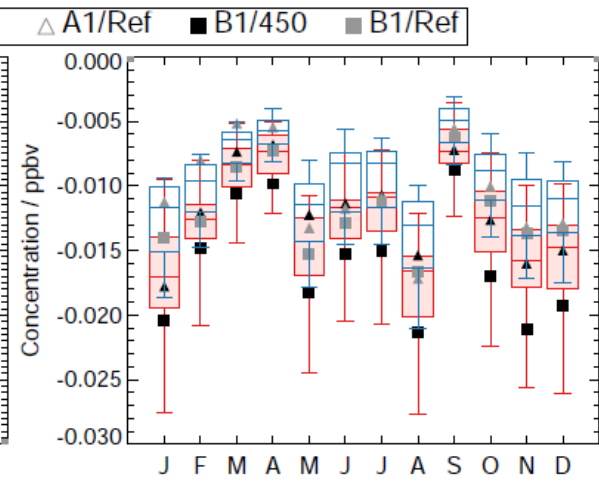

(b) Ave. change in surface $\mathrm{NO}_{x}$ conc.

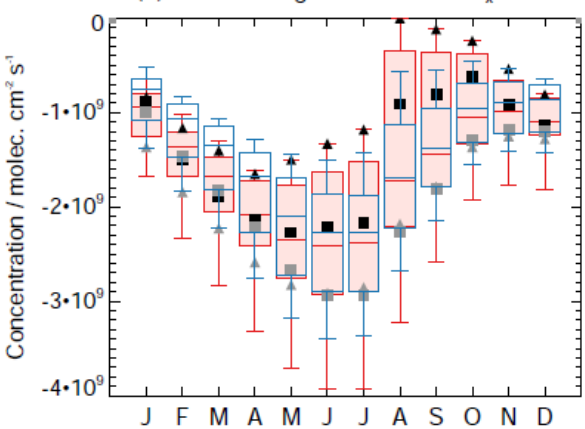

(d) Ave. change in surface $\mathrm{O}_{3} \mathrm{df}$

Fig. 11. Same as Fig. 7 but for Europe (Fig. 6).

low emitting crop PFT is replaced with more strongly emitting PFTs. In Europe, these increases were small with surface isoprene concentrations only increasing by a maximum of $+0.05 \mathrm{ppb}$ in the $\mathrm{NH}$ growing season. However, as a result of the high ambient $\mathrm{NO}_{\mathrm{x}}$ conditions in Europe (Fig. 5) we found moderate increases in surface $\mathrm{O}_{\mathrm{x}}$ of up to $+0.70 \mathrm{ppb}$ (Fig. 11c). The largest increases in surface isoprene and $\mathrm{O}_{x}$ were simulated for the $\mathrm{B} 1$ scenarios in which the lower rates of population growth and consumption resulted in more afforestation and grassland expansion. Small areas of cultivation of SRC crops for biofuel drove slightly higher mixing ratios in the B1/450 scenario compared with the B1/Reference.

In India, elevated surface isoprene concentrations resulting from afforestation/increasing grassland area were supplemented by emissions from strongly isoprene emitting SRC crops. Surface isoprene generally increased by between $+0.34 \mathrm{ppb}$ above the ZLUC during the warmer part of the year $\approx$ March-November. The greater area of SRC crop cultivation in the 450 scenarios resulted in greater increases in $\mathrm{A} 1 / 450$ and B1/450 compared to the Reference scenarios. As in Europe, the increases in surface isoprene combined with high background $\mathrm{NO}_{\mathrm{x}}$, drove increases in surface $\mathrm{O}_{\mathrm{x}}$ of +0.01 to $+0.27 \mathrm{ppb}$ (Fig. 10c) above the ZLUC.

\subsubsection{Boreal Eurasia, China, temperate North America}

Changes in surface oxidant concentrations in boreal Eurasia, China and temperate North America were strongly in- fluenced by increases in cropland for cultivating SRC crops for biofuel production. Because SRC crops are not currently commercially cultivated, their estimated area was globally distributed (Sect. 2.2). However, as boreal Eurasia, China and temperate North America have large areas of available land, much of the estimated area for SRC crop was allocated to these regions. Cropland area for food production actually contracted in China (Fig. 3) and temperate North America in the median A1 and B1 scenarios and in boreal Eurasia in the median B1 scenario as a result of increased production in other regions, as discussed in Sect. 3.3.2.

Figures 12, 13, and 14 show changes in surface oxidant levels at the regional scale. The strongly isoprene emitting SRC crops drove increases in surface isoprene mixing ratios, which peaked in the $\mathrm{NH}$ summer (April-October) at \pm 0.4 to $+0.7 \mathrm{ppb}$ in 2030. The high background $\mathrm{NO}_{\mathrm{x}}$ (Fig. 5c, d) in these three regions resulted in surface $\mathrm{O}_{\mathrm{x}}$ increasing by \pm 0.10 to $+1.20 \mathrm{ppb}$, in conjunction with surface isoprene. The greatest increases occurred with the 450 biofuel scenarios (A1 and B1), where $41 \%$ of the biofuel demand, corresponding to $9.12 \times 10^{11} \mathrm{~m}^{2}$ (compared to $6.81 \times 10^{11} \mathrm{~m}^{2}$ in the Reference scenario), was met through SRC crop cultivation. Outside of the $\mathrm{NH}$ growing season there was little change in surface oxidant levels in these regions.

Surface $\mathrm{NO}_{\mathrm{x}}$ decreased to varying extents in boreal Eurasia, China and temperate North America. In the latter two regions this was driven by afforestation increasing the forest 


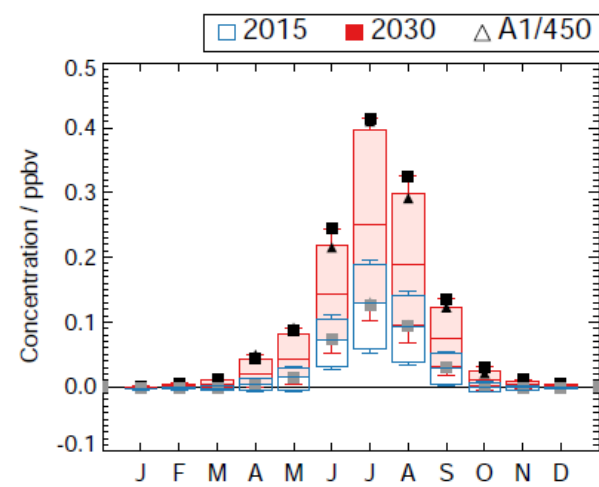

(a) Ave. change in surface ISOP conc.

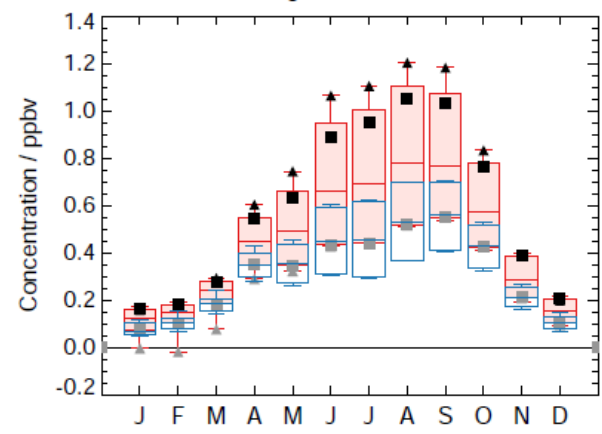

(c) Ave. change in surface $\mathrm{O}_{\mathrm{x}}$ conc.

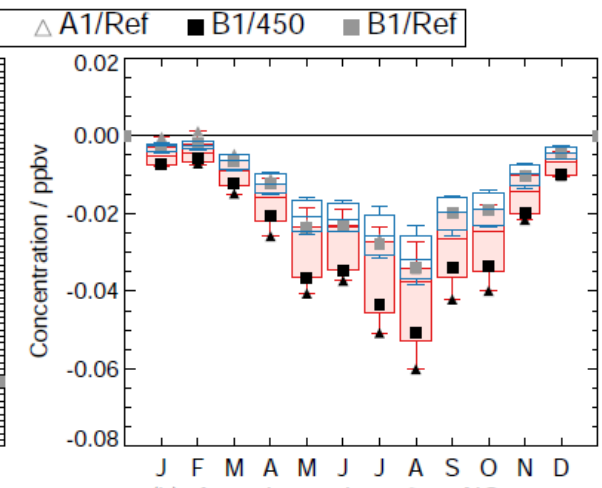

(b) Ave. change in surface $\mathrm{NO}_{\mathrm{x}}$ conc.

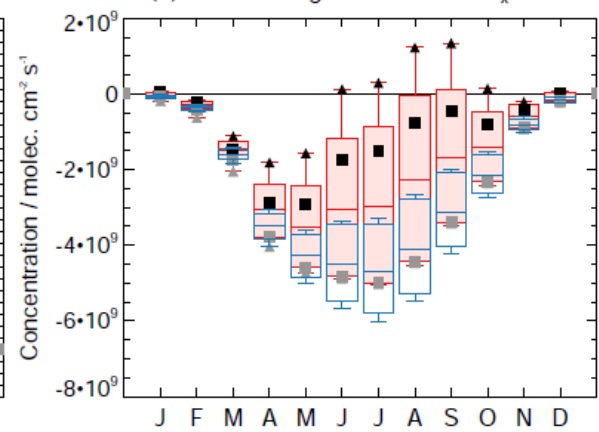

(d) Ave. change in surface $\mathrm{O}_{3} \mathrm{df}$

Fig. 12. Same as Fig. 7 but for China (Fig. 6).

canopy and thus reducing $\mathrm{NO}_{\mathrm{x}}$ release to the atmosphere (Figs. 14c, 13c). Afforestation in China also drove decreases in the summertime surface $\mathrm{O}_{3}$ flux (i.e. increases in $\mathrm{O}_{3}$ dry deposition to the biosphere) of up to $-5.0 \times$ $10^{9}$ molecules cm $\mathrm{c}^{-2} \mathrm{~s}^{-1}$ (Fig. 12d). These decreases were smaller in 2030 compared with 2015 and smallest for the 450 scenarios where biofuel cultivation and resultant increases in $\mathrm{O}_{\mathrm{x}}$ were maximised. In fact, between June-September small increases in $\mathrm{O}_{3}$ surface flux were simulated in the $\mathrm{A} 1 / 450$ scenario. It is possible that this was driven by elevated surface $\mathrm{O}_{3}$, which was particularly high in China (Ganzeveld et al., 2010). Surface $\mathrm{O}_{3}$ fluxes generally increased (i.e. $\mathrm{O}_{3}$ emission to the atmosphere increased) in boreal Eurasia and temperate North America, driven by reduced LAI and surface roughness as a result of deforestation/conversion of grasslands. These increases, up to $+2.1 \times 10^{9}$ molecules $\mathrm{cm}^{-2} \mathrm{~s}^{-1}$ (Fig. 14d) and $+6.0 \times 10^{9}$ molecules $\mathrm{cm}^{-2} \mathrm{~s}^{-1}$ (Fig. 13d), respectively in 2030, were greater in the A1/450 and B1/450 scenarios where cropland expansion for SRC crop cultivation was maximised.

\subsubsection{Local scale changes in atmospheric oxidant chemistry}

We acknowledge that changes over large geographical regions will mask changes at local and country-level scales and will likely be more pertinent to surface air quality. In this study the greatest changes in surface oxidant chemistry (above ZLUC) at the $4 \times 5^{\circ}$ grid scale occurred in areas of southern Africa, southern Brazil, Colombia, southwest boreal Eurasia, northeast China and northeast temperate North America.

In southern Africa, the largest LUC increases to meet food demands were simulated in South Sudan, Ethiopia, southern Chad, West Africa (including Ghana, Ivory Coast, Senegal, Burkina Faso), NE Nigeria, Angola, Botswana and southern Kenya, resulting in surface composition changes up to an order of magnitude greater than at the regional scale. Isoprene decreased by up to $-5.5 \mathrm{ppb}$ in September and there were corresponding increases in surface $\mathrm{O}_{\mathrm{x}}$ and $\mathrm{O}_{3}$ dry deposition flux of up to $1.65 \mathrm{ppb}$ and $1.55 \times 10^{10}$ molecules $\mathrm{cm}^{-2} \mathrm{~s}^{-1}$, respectively. Previous studies have also simulated reduced surface isoprene and corresponding increases in surface $\mathrm{O}_{\mathrm{x}}$ in southern Africa (Wu et al., 2012; Ganzeveld et al., 2010), but these studies have focused on deforestation in central Africa, predominantly the Democratic Republic of the Congo, which is not included in PLUM.

At the local scale isoprene mixing ratios in southern Brazil (Fig. 3) decreased by up to -10 to $-12.5 \mathrm{ppb}$ during the wet season, however, the corresponding increases in surface $\mathrm{O}_{\mathrm{x}}$ were similar to changes at the regional scale, +0.40 to $+1.00 \mathrm{ppb}$ above the ZLUC. Locally, $\mathrm{O}_{3}$ fluxes were an order of magnitude larger than increases at the regional scale, up to +3.0 to $+12 \times 10^{9}$ molecules $\mathrm{cm}^{-2} \mathrm{~s}^{-1}$ above the ZLUC. In contrast, Ganzeveld et al. (2010) observed decreases in $\mathrm{O}_{3}$ 


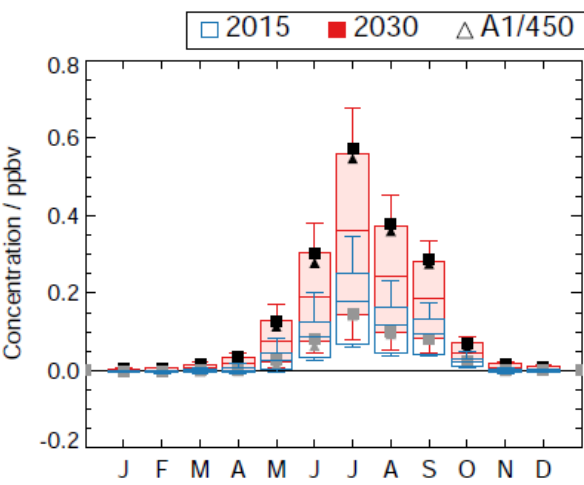

(a) Ave. change in surface ISOP conc.

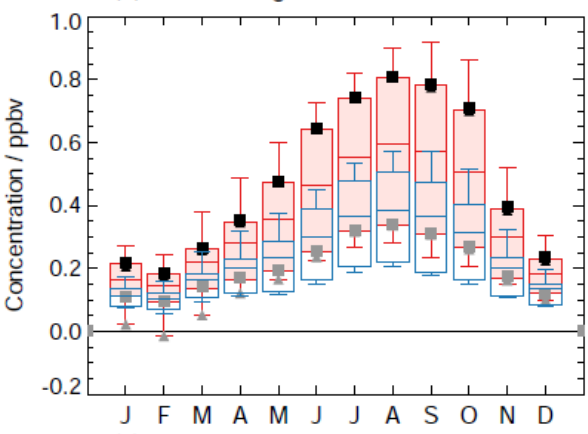

(c) Ave. change in surface $\mathrm{O}_{x}$ conc.

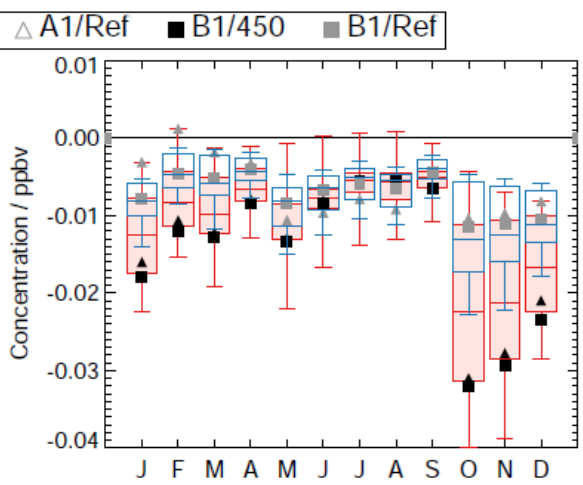

(b) Ave. change in surface $\mathrm{NO}_{\mathrm{x}}$ conc

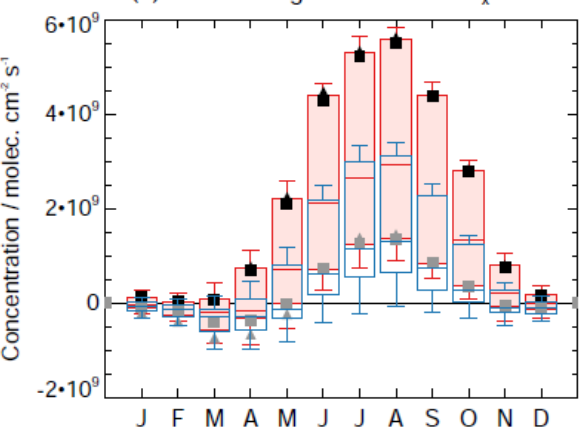

(d) Ave. change in surface $\mathrm{O}_{3} \mathrm{df}$

Fig. 13. Same as Fig. 7 but for temperate North America (Fig. 6).

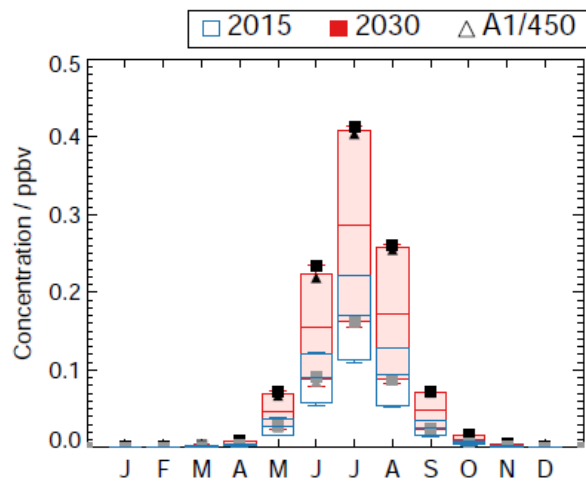

(a) Ave. change in surface ISOP conc.

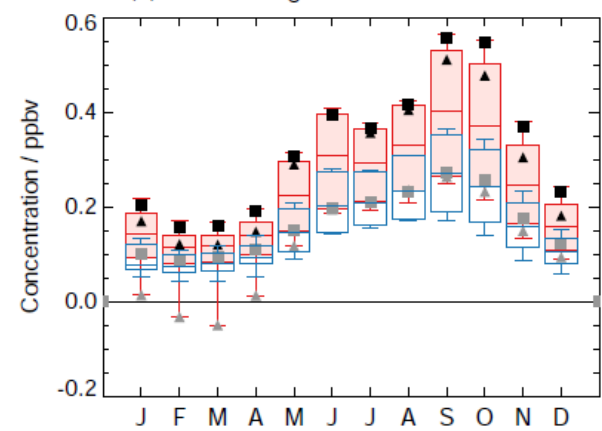

(c) Ave. change in surface $\mathrm{O}_{x}$ conc.

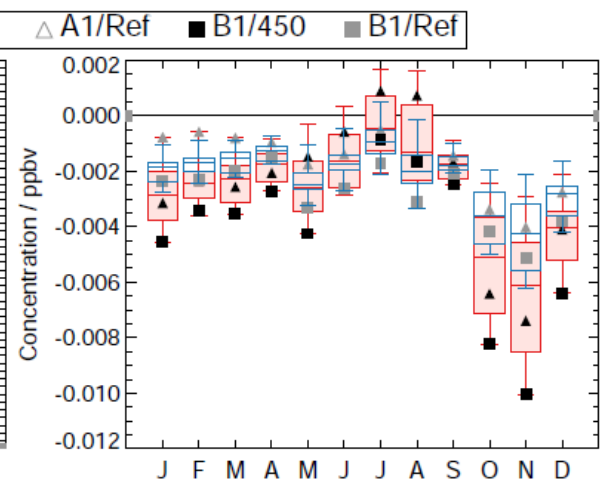

(b) Ave. change in surface $\mathrm{NO}_{x}$ conc.

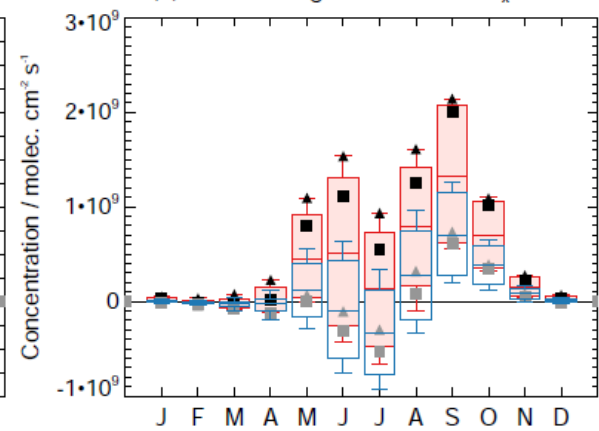

(d) Ave. change in surface $\mathrm{O}_{3} \mathrm{df}$

Fig. 14. Same as Fig. 7 but for boreal Eurasia (Fig. 6). 
deposition, but these were localized to certain regions in the Amazon. It should be noted that isoprene mixing ratios over tropical, low $\mathrm{NO}_{\mathrm{x}}$ areas are over estimated in global models as a result of a lack of understanding and/or simplification of the complicated chemical and phenological processes (Ashworth et al., 2012). Studies by Archibald et al. (2010) and Hewitt et al. (2011) have indicated that modifying the isoprene chemistry to simulate more realistic $\mathrm{OH}$ concentrations and including circadian cycles in isoprene emissions, respectively, improves the agreement between observations and model simulations. However, in this study isoprene mixing ratios, and possibly the differences in mixing ratios between ZLUC and LUC scenarios, are likely over estimated in tropical regions.

Figure 3 shows that SRC crop cultivation was localized to southwest boreal Eurasia, northeast China and northeast temperate North America. The localization of the LUC in northeast China explains the pronounced seasonality in the changes over this region. The maximum increases in surface isoprene across the range of scenarios and within each region were +2.0 to $+6.5 \mathrm{ppb}$ ( $\mathrm{SW}$ boreal Eurasia), +1.0 to $+7.5 \mathrm{ppb}$ (NE China) and +2.0 to $+5.0 \mathrm{ppb}$ (NE temperate North America). Peak summertime surface $\mathrm{O}_{\mathrm{x}}$ was subsequently increased by $+5.0 \mathrm{ppb}$ (SW boreal Eurasia), +6.0 to $+12.0 \mathrm{ppb}$ (NE China) and +1.5 to $+6.0 \mathrm{ppb}$ (NE temperate North America). These large increases have the potential to reduce air quality, particularly in NE China and NE temperate North America where surface $\mathrm{O}_{\mathrm{x}}$ already reaches approximately $50-60 \mathrm{ppb}$ during summer months (Fig. 3). Reduced LAI and surface roughness through deforestation and conversion of grasslands also drove large reductions in dry deposition at the local level; +10.0 to $+28 \times$ $10^{9}$ molecules $\mathrm{cm}^{-2} \mathrm{~s}^{-1}$ (SW boreal Eurasia) and +14.0 to $+48.0 \times 10^{9}$ molecules $\mathrm{cm}^{-2} \mathrm{~s}^{-1}$ (NE temperate North America). In NE China $\mathrm{O}_{3}$ dry deposition decreased by a maximum of $-300 \times 10^{9}$ molecules $\mathrm{cm}^{-2} \mathrm{~s}^{-1}$.

Examining the changes in local atmospheric composition showed that air quality was adversely affected by the simulated LUC scenarios, largely through increasing $\mathrm{O}_{3}$ mixing ratios at the surface. It is important, therefore, that detailed studies are conducted at the regional and local scale (such as by Ashworth et al. (2012)), to better understand LUC effects and to explore the possibilities for minimizing detrimental changes to atmospheric composition

\section{Discussion and concluding remarks}

We have presented a quantitative probabilistic assessment of the impact of LUC, associated with growing food production demands, on the distribution and magnitude of isoprene emissions and subsequently on atmospheric oxidant chemistry. We use an ensemble $(n=1000)$ of LUC realizations, generated by a reduced order LUC model, that are derived from the A1 and B1 IPCC AR4/SRES sce- narios. From each ensemble we selected realizations that fell within the IQR $(n=500 \times 2)$ and considered two future biofuel scenarios resulting in four scenarios (A1/450, $\mathrm{A} 1 /$ Reference, B1/450 and B1/Reference) with $n=500$ realizations for which we assessed changes in isoprene basal emissions using the MEGAN model. We found that LUC values of $-1.50 \times 10^{12} \mathrm{~m}^{2}$ to $+6.06 \times 10^{12} \mathrm{~m}^{2}$ led to changes in the global isoprene burden of -3.5 to $+2.8 \mathrm{Tg} \mathrm{yr}^{-1}$ in 2015 and -7.7 to $+6.4 \mathrm{Tg} \mathrm{yr}^{-1}$ in 2030 . Using realizations that defined the median and IQR statistics for each scenario $(n=12$ realizations in 2015 and 2030) we ran a total of 24 experiments with the GEOS-Chem model to assess the effect of LUC on surface oxidant chemistry.

Our predicted changes in the global isoprene burden are smaller than the changes estimated by previous work, e.g. Ganzeveld et al. (2010); Wu et al. (2012). However, these two studies reported LUC to 2050 and Ganzeveld et al. (2010) used the A2 emissions scenario, which describes larger population increases and less technological dispersion relative to A1 and B1 (Table 1), resulting in a correspondingly large increase in cropland area of $+11 \times 10^{12} \mathrm{~m}^{2}$. We find that replacing isoprene-emitting forest and grasslands with less strongly isoprene-emitting crops reduces surface isoprene mixing ratios, but that cultivation of strongly isoprene-emitting SRC crops for biofuel production increases surface isoprene mixing ratios, in agreement with previous work (Ganzeveld et al., 2010; Wu et al., 2012; Ashworth et al., 2012). In general we find that changes to surface isoprene and oxidant chemistry are larger in 2030 than in 2015.

We find that projected LUC due to increasing food production and biofuel cultivation has only a small effect on surface oxidant chemistry at the global scale, in agreement with previous work (Ganzeveld et al., 2010; Wu et al., 2012; Ashworth et al., 2012). We find larger changes at the regional and, particularly, at the local scale which result in degradation of surface air quality. Surface $\mathrm{O}_{x}$ mixing ratios increased in all regions that experienced substantial LUC, either through decreasing isoprene concentrations in a low- $\mathrm{NO}_{\mathrm{x}}$ environment (e.g. southern Africa, Brazil, tropical South America) or increasing isoprene concentrations in a high- $\mathrm{NO}_{\mathrm{x}}$ environment (e.g. temperate North America, Europe, China). The average increase in surface $\mathrm{O}_{\mathrm{x}}$ across the eight regions we studied, relative to ZLUC, was between $0.05 \mathrm{ppb}$ (Europe) and $0.8 \mathrm{ppb}$ (China). At the local scale over those regions, monthly surface $\mathrm{O}_{\mathrm{x}}$ concentrations increased by up to 5 ppb, 6 ppb and 12 ppb in SW boreal Eurasia, NE temperate North America and NE China, respectively, during the NH summer. These increases compound existing high surface $\mathrm{O}_{x}$ concentrations in these regions where summertime mean monthly surface $\mathrm{O}_{\mathrm{x}}$ can be between 50 $70 \mathrm{ppb}$, and will likely result in an increased frequency of air quality exceedances of the daily maximum $8 \mathrm{~h}$ mean of $100 \mathrm{~g} \mathrm{~m}^{3}$ (or $47 \mathrm{ppb}$ ) determined by the World Health Organization (WHO, 2000). Avnery et al. (2011a,b) showed that exposure of soybean, maize and wheat to increased 
surface $\mathrm{O}_{3}(+2$ to $+15 \mathrm{ppb})$, driven by the $\mathrm{A} 2$ and $\mathrm{B} 1$ IPCC AR4/SRES scenarios, led to reduced crop yields of -1.9 to $-38 \%$, depending on region, crop and scenario. Our reported increases in $\mathrm{O}_{3}$ are slightly smaller than those used in that study, but they are still sufficiently large to reduce crop productivity.

We selected a likely range of LUC realizations from which to investigate future BVOC and surface oxidant chemistry. We found that the largest increases in the global isoprene burden occurred with the A1/450 scenarios and were driven by elevated emissions in the $\mathrm{NH}$ summer from SRC crop cultivation, predominantly located in boreal Eurasia, China and temperate North America. The greatest decreases occurred for the A1/Reference scenario combination which represented maximum LUC for food production, but minimum increase in SRC crops. Within each region the scenarios driving the maximum and minimum differences in BVOC mixing ratios and surface oxidant mixing ratios depended on the processes driving LUC in that region. In temperate North America, boreal Eurasia and China biofuel production, particularly from SRC crops was the dominant driver for LUC with the result that the greatest differences occurred in the 450 scenarios and the least differences in the Reference scenarios with little differentiation between the $\mathrm{A} 1$ and $\mathrm{B} 1$ scenarios. In contrast, food production drove LUC in Brazil, southern Africa and tropical South America where, depending on biofuel production, the greatest differences in BVOC and surface oxidant mixing ratios occurred in the A1/450 or A1/Reference scenarios. In Europe where LUC was driven by afforestation and increases in grassland area the greatest increases occurred in the B1/Reference scenario. The extent to which BVOC and surface oxidant mixing ratios varied across the scenarios was dependent on the region and season. We generally found a greater range when the difference from the ZLUC was greater. From this study we suggest that LUC drives uncertainty in surface isoprene, $\mathrm{O}_{\mathrm{x}}, \mathrm{NO}_{\mathrm{x}}$ and $\mathrm{O}_{3}$ deposition flux by approximately $0.35 \mathrm{ppb}, 0.35 \mathrm{ppb}, 0.03 \mathrm{ppb}$ and $4.3 \times 10^{9}$ molecules $\mathrm{m}^{-2} \mathrm{~s}^{-1}$, respectively.

We found, in agreement with previous work, that the nature and location of the LUC was important. This is highlighted by comparing increasing crop cultivation for biofuel production here and in the study by Ashworth et al. (2012). It is apparent from both studies that locating large areas of highly isoprene emitting SRC crops has substantial effects on the regional and local isoprene burden with related impacts on surface $\mathrm{O}_{\mathrm{x}}$ chemistry. In this study, $1.29-4.0 \times 10^{11} \mathrm{~m}^{2}$ SRC crop was principally located in boreal Eurasia, temperate North America and China where peak summertime surface $\mathrm{O}_{\mathrm{x}}$ mixing ratios increased by +0.2 to $+1.2 \mathrm{ppb}$. In contrast, Ashworth et al. (2012) located most of $9.2 \times 10^{11} \mathrm{~m}^{2}$ SRC crop area in Eastern Europe with the result that peak (summertime) mean monthly $\mathrm{O}_{3}$ mixing ratios increased by up to $+2.26 \mathrm{ppb}$. These model studies agree with field-based measurements that show elevated isoprene from SRC crops in the United Kingdom and Sweden (Copeland et al., 2012; Oloffson et al., 2005).

We found that increased cultivation of oil palm did not have large impacts on surface isoprene mixing ratios or surface oxidant chemistry in contrast to Ashworth et al. (2012). This was partly because we (a) widely distributed oil palm across the globe rather than locating production over the relatively small region of SE Asia and (b) considered a smaller area of oil palm $\left(1.62-3.70 \times 10^{10} \mathrm{~m}^{2}\right.$ compared with $6.9 \times$ $10^{11} \mathrm{~m}^{2}$ used by Ashworth et al., 2012) as we distributed biofuel production across several crops (Table 2). This suggests that distributing biofuel production across several crops, and over several geographical regions, may minimise air quality impacts, although we acknowledge that the cost of a network of processing plants may increase transport costs and the general efficacy of this approach. We also found that high isoprene emissions from oil palm crops for biodiesel production did not drive changes in surface oxidant chemistry. Where we distributed oil palm cultivation across oil palm growing countries in SE Asia, any increases in isoprene emissions appeared to be offset by increased food production, where strongly isoprene emitting forest and grassland was converted to low-isoprene emitting crops.

The importance of LUC, compared with climate change and $\mathrm{CO}_{2}$ fertilization, in determining future emissions of BVOCs and surface oxidant chemistry was highlighted by Lathiere et al. (2010). We have focused on the effects of LUC which will likely drive these compound changes over our study period. We find similar changes to the surface oxidant chemistry burden as Wu et al. (2012), when climate change and increased atmospheric $\mathrm{CO}_{2}$ are considered. However, we likely underestimated increases in BVOC emissions and corresponding decreases in surface $\mathrm{O}_{\mathrm{x}}$ in the remote regions of boreal Eurasia if climate change results in replacement of the lower isoprene-emitting needleleaf PFT to the higher emitting broadleaf PFT. These types of land cover change could also enhance dry deposition as the LAI increases. Similarly we do not account for the impacts of a warmer, drier climate which could drive decreases in broadleaf tree coverage and subsequent decreases in isoprene emission and dry deposition as well as decreasing soil $\mathrm{NO}_{\mathrm{x}}$ emissions.

Overestimation of crop yield increases and, therefore underestimation of cropland expansion for food production, must also be considered as the PLUM model does not account for the impact of climate change on the rates of yield increases. We also do not consider the feedback of the changing vegetation to the meteorology.

We believe that the probabilistic approach of investigating LUC and the subsequent impact on atmospheric chemistry illustrated in this work is better suited than conventional IAMs to capture the stochastic nature of the human element that is driving the underlying LUC. The probabilistic approach also has the advantage of providing uncertainty bounds on the estimates that enable actionable projections for policy makers that is sorely needed. 
Acknowledgements. This work was supported by the Natural Environment Research Council (grant number NE/F003919/1). GEOS-Chem is centrally maintained at Harvard University by the NASA Atmospheric Composition Modelling and Analysis Program (ACMAP). We thank Tiffany Duhl at NCAR, Colorado for her help and advice with the MEGAN model. CJH also thanks Annemarie Fraser for producing the modified TransCom plot, Mark Parrington for his assistance with the GEOS-Chem model and Anthony Bloom for the initial development of the IDL downscaling routine. PIP acknowledges the support of the Leverhulme Trust.

Edited by: B. N. Duncan

\section{References}

Archibald, A. T., Cooke, M. C., Utembe, S. R., Shallcross, D. E., Derwent, R. G., and Jenkin, M. E.: Imp acts of mechanistic changes on $\mathrm{HO}_{\mathrm{x}}$ formation and recycling in the oxidation of isoprene, Atmos. Chem. Phys., 10, 8097-8118, doi:10.5194/acp-128097-2010, 2010.

Ashworth, K., Folberth, G., Hewitt, C. N., and Wild, O.: Impacts of near-future cultivation of biofuel feedstocks on atmospheric composition and local air quality, Atmos. Chem. Phys., 12, 919939, doi:10.5194/acp-12-919-2012, 2012.

Avnery, S., Mauzerall, D. L., Liu, J., and Horowitz, L. W.: Global crop yield reductions due to surface ozone exposure: 2. year 2030 potential crop production losses and economic damage under two scenarios of $\mathrm{O}_{3}$ pollution, Atmos. Environ., 45, 2297-2309, 2011a.

Avnery, S., Mauzerall, D. L., Liu, K., and Horowitz, L. W.: Global crop yield reductions due to surface ozone exposure: 1. year 2000 crop production losses and economic damage, Atmos. Environ., 45, 2284-2296, $2011 b$.

Balmford, A., Green, R., and Scharlemann, J.: Sparing land for nature: exploring the potential impact if changes in agricultural yield on the area needed for crop production, Glob. Change Biol., 11, 1594-1605, doi:10.1111/j.1365-2486.2005.001035.x, 2005.

Barth, M., McFadden, J. P., Sun, J. L., Wiedinmyer, C., Chuang, P., Collins, D., Griffin, R., Hannigan, M., Karl, T., Kim, S. W., Lasher-Trapp, S., Levis, S., Litvak, M., Mahowald, N., Moore, K., Nandi, S., Nemitz, E., Nenes, A., Potosnak, M., Raymond, T. M., Smith, J., Still, C., and Stroud, C.: Couling between land ecosystems and the atmospheric hydrologic cycle through biogenic aerosol pathways, B. Am. Meteorol. Soc., 86, 1738-1742, doi:10.1175/BAMS-86-12-1738, 2005.

Baumanns, K., Rounsevell, M., Murray-Rust, D., Hardacre, C., Palmer, P. I., Arneth, A., and Cui, X.: Applying Occam's razor to global agricultural land use change, Agr. Syst., submitted, 2013.

Beddington, J.: Food security: contributions from science to a new and greener revolution, Philos. T. Roy. Soc. B, 365, 61-71, doi:10.1098/rstb.2009.0201, 2010.

Bey, I., Jacob, D., Yantosca, R., Logan, J., Field, B., Fiore, A., Li, Q., Liu, H., Mickley, M., and Schultz, M.: Global modeling of tropospheric chemistry with assimilated meteorology: model description and evaluation, J. Geophys. Res., 106, 23097-23114, 2001.
Brovkin, V., Claussen, M., Driesschaert, E., Fichefet, T., Kicklighter, D., Loutre, M. F., Matthews, H. D., Ramankutty, N., Schaeffer, M., and Sokolov, A.: Biogeophysical effects of historical land cover changes simulated by six Earth system models of intermediate complexity, Clim. Dynam., 26, 587-600, doi:10.1007/s00382-005-0092-6, 2006.

Centre for International Earth Science Information Network (CIESIN): Downscaled projections for country level population and GDP data based on the SRES, 1990-2100, Tech. rep., Columbia University, available at: http://sedac.ciesin.columbia. edu/theme/population/data/sets/browse/2 (last access: 21 December 2012), 2002.

Copeland, N., Cape, J. N., and Heal, M. R.: Volatile organic compound emissions from Miscanthus and short rotation coppice willow bioenergy crops, Atmos. Environ., 60, 327-335, doi:10.1016/j.atmosenv.2012.06.065, 2012.

Foley, J. A., Ramankutty, N., Brauman, K. A., Cassidy, E. S., Gerber, J. S., Johnston, M., Mueller, N. D., O'Connell, C., Ray, D. K., West, P. C., Balzer, C., Bennett, E. M., Carpenter, S. R., Hill, J., Monfreda, C., Polasky, S., Rockstrom, J., Sheehan, J., Siebert, S., Tilman, D., and Zaks, D. P. M.: Solutions for a cultivated planet, Nature, 478, 337-342, doi:10.1038/nature10452, 2011.

Fowler, D., Nemitz, E., Misztal, P., Di Marco, C., Skiba, U., Ryder, J., Helfter, C., Cape, J. N., Owen, S., Dorsey, J., Gallagher, M. W., Coyle, M., Phillips, G., Davison, B., Langford, B., MacKenzie, R., Muller, J., Siong, J., Dari-Salisburgo, C., Di Carlo, P., Aruffo, E., Giammaria, F., Pyle, J. A., and Hewitt, C. N.: Effects of land use on surface-atmosphere exchanges of trace gases and energy in Borneo: comparing fluxes over oil palm plantations and a rainforest, Philos. T. Roy. Soc. B, 366, 3196-3209, doi:10.1098/rstb.2011.0055, 2011.

Gaffin, S. R., Rosenzweig, C., Xing, X. S., and Yetman, G.: Downscaling and geo-spatial gridding of socio-economic projections from the IPCC Special Report on Emissions Scenarios (SRES), Global Environ. Chang., 14, 105-123, doi:10.1016/j.gloenvcha.2004.02.004, 2004.

Gallagher, E.: The Gallagher Review of the Indirect Effects of Biofuels Production, Tech. rep., UK Renewable Fuels Agency, London, UK, 2008.

Ganzeveld, L., Bouwman, L., Stehfest, E., van Vuuren, D. P., Eickhout, B., and Lelieveld, J.: Impact of future land use and land cover changes on atmospheric chemistryclimate interactions, J. Geophys. Res.-Atmos., 115, D23301, doi:10.1029/2010JD014041, 2010.

Godfray, H. C. J., Beddington, J. R., Crute, I. R., Haddad, L., Lawrence, D., Muir, J. F., Pretty, J., Robinson, S., Thomas, S. M., and Toulmin, C.: Food security: the challenge of feeding 9 billion people, Science, 327, 812-818, doi:10.1126/science.1185383, 2010.

Guenther, A., Karl, T., Harley, P., Wiedinmyer, C., Palmer, P. I., and Geron, C.: Estimates of global terrestrial isoprene emissions using MEGAN (Model of Emissions of Gases and Aerosols from Nature), Atmos. Chem. Phys., 6, 3181-3210, doi:10.5194/acp-63181-2006, 2006. 
Gurney, K. R., Law, R. M., Denning, A. S., Rayner, P. J., Baker, D., Bousquet, P., Bruhwiler, L., Chen, Y.-H., Ciais, P., Fan, S., Fung, I. Y., Gloor, M., Heimann, M., Higuchi, K., John, J., Maki, T., Maksyutov, S., Masarie, K., Peylin, P., Prather, M., Pak, B. C., Randerson, J., Sarmiento, J., Taguchi, S., Takahashi, T., and Yuen, C.-W.: Towards robust regional estimates of $\mathrm{CO}_{2}$ sources and sinks using atmospheric transport models, Nature, 415, 626-630, doi:10.1038/415626a, 2002.

Heistermann, M., Muller, C., and Ronneberger, K.: Land in sight? Achievements, deficits and potentials of continental to global scale land-use modeling, Agr. Ecosyst. Environ., 114, 141-158, doi:10.1016/j.agee.2005.11.015, 2006.

Hewitt, C. N., MacKenzie, A. R., Di Carlo, P., Di Marco, C. F., Dorsey, J. R., Evans, M., Fowler, D., Gallagher, M. W., Hopkins, J. R., Jones, C. E., Langford, B., Lee, J. D., Lewis, A. C., Lim, S. F., McQuaid, J., Misztal, P., Moller, S. J., Monks, P. S., Nemitz, E., Oram, D. E., Owen, S. M., Phillips, G. J., Pugh, T. A. M., Pyle, J. A., Reeves, C. E., Ryder, J., Siong, J., Skiba, U., and Stewart, D. J.: Nitrogen management is essential to prevent tropical oil palm plantations from causing groundlevel ozone pollution, P. Natl. Acad. Sci. USA, 106, 1844718451, doi:10.1073/pnas.0907541106, 2009.

Hewitt, C. N., Ashworth, K., Boynard, A., Guenther, A., Langford, B., MacKenzie, A. R., Misztal, P., Nemitz, E., Owen, S. M., Possell, M., Pugh, T. A. M., Ryan, A. C., and Wild, O.: Groundlevel ozone influenced by circadian control of isoprene emissions, Nature, 4, 671-674, doi:10.1038/NGEO.01271, 2011

Howarth, R. W., Bringezu, S., Bekunda, M., de Fraiture, C., Maene, L., Martinelli, L. A., and Sala, O. E.: Rapid assessment on biofuels and the environment: overview and key findings, in: Biofuels: Environmental Consequences and Interactions with Changing Land Use, edited by: Howarth, R. W., Proceedings from the SCOPE International Biofuels Project Rapid Assessment on Biofuels, 22-25 September 2008, Gummersbach, Germany, 1-13, Cornell Univ., 2009.

IEA: From 1st to 2nd Generation Biofuel Technologies, Tech. rep., International Energy Agency, Paris, France, available at: http://www.iea.org/publications/freepublications/publication/ name,3798, en.html (last access: 21 December 2012), 2008.

IEA: World Energy Outlook Executive Summary, Tech. rep., International Energy Agency, Paris, France, 2009.

IEA: Sustainable Production of Second-Generation Biofuels, Tech. rep., International Energy Agency, Paris, France, available at: http://www.iea.org/publications/freepublications/publication/ biofuels_exec_summary.pdf (last access: 21 December 2012), 2010.

IEA: Technology Roadmap: Biofuels for Transport, Tech. rep., International Energy Agency, Paris, France, available at: http://www.iea.org/publications/freepublications/publication/ biofuels_roadmap.pdf (last access 21 December 2012), 2011.

IPCC: Fourth Assessment Report: Climate Change 2007: The AR4 Synthesis Report, Cambridge University Press, available at: http: //www.ipcc.ch/ipccreports/ar4-wg1.htm, 2007.

IPCC/SRES: IPCC Special Report Emissions Scenarios: Summary for Policymakers: A Special Report of IPCC Working Group III, Cambridge University Press, 2000.

Lambin, E. F., Rounsevell, M. D. A., and Geist, H. J.: Are agricultural land-use models able to predict changes in land-use intensity?, Agr. Ecosyst. Environ., 82, 321-331, doi:10.1016/S0167-
8809(00)00235-8, 2000.

Lathiere, J., Hewitt, C. N., and Beerling, D. J.: Sensitivity of isoprene emissions from the terrestrial biosphere to 20th century changes in atmospheric $\mathrm{CO}_{2}$ concentration, climate, and land use, Global Biogeochem. Cy., 24, GB1004, doi:10.1029/2009GB003548, 2010.

Misztal, P. K., Nemitz, E., Langford, B., Di Marco, C. F., Phillips, G. J., Hewitt, C. N., MacKenzie, A. R., Owen, S. M., Fowler, D., Heal, M. R., and Cape, J. N.: Direct ecosystem fluxes of volatile organic compounds from oil palms in South-East Asia, Atmos. Chem. Phys., 11, 8995-9017, doi:10.5194/acp-11-89952011, 2011.

Muetzelfeldt, R. and Massheder, J.: The Simile visual modelling environment, Eur. J. Agron., 18, 345-358, doi:10.1016/S11610301(02)00112-0, 2003.

Oloffson, M., Ek-Olausson, B., Jensen, N., Langer, S., and Ljungsröm, E.: The flux of isoprene from a willow coppice plantation and the effect of local air quality, Atmos. Environ., 39, 2061-2070, 2005.

Olson, J.: World Ecosystems (WE1.4): Digital raster data on a 10 minute geographic $1080 \times 2160$ grid, in: Global Ecosystems Database, version 1.0, Disc A, 1992.

Scanlon, B. R., Reedy, R. C., Stonestrom, D. A., Prudic, D. E., and Dennehy, K. F.: Impact of land use and land cover change on groundwater recharge and quality in the southwestern US, Glob. Change Biol., 11, 1577-1593, doi:10.1111/j.13652486.2005.01026.x, 2005.

Searchinger, T., Heimlich, R., Houghton, R. A., Dong, F., Elobeid, A., Fabiosa, J., Tokgoz, S., Hayes, D., and Yu, T.-H.: Use of US croplands for biofuels increases greenhouse gases through emissions from land-use change, Science, 319, 1238 1240, doi:10.1126/science.1151861, 2008.

Simpson, D., Winiwarter, W., Borjesson, G., Cinderby, S., Ferreiro, A., Guenther, A., Hewitt, C. N., Janson, R., Khalil, M. A. K., Owen, S., Pierce, T. E., Puxbaum, H., Shearer, M., Skiba, U., Steinbrecher, R., Tarrason, L., and Oquist, M. G.: Inventorying emissions from nature in Europe, J. Geophys. Res.-Atmos., 104, 8113-8152, doi:10.1029/98JD02747, 1999.

Smith, P., Gregory, P. J., van Vuuren, D., Obersteiner, M., Havlík, P., Rounsevell, M. D. A., Woods, J., Stehfest, E., and Bellarby, J.: Competition for land, Philos. T. Roy. Soc. B, 365, 2941-2957, doi:10.1098/rstb.2010.0127, 2010.

Tilman, D., Fargione, J., Wolff, B., D’Antonio, C., Dobson, A., Howarth, R., Schindler, D., Schlesinger, W. H., Simberloff, D., and Swackhamer, D.: Forecasting agriculturally driven global environmental change, Science, 292, 281-284, doi:10.1126/science.1057544, 2001.

Tilman, D., Balzer, C., Hill, J., and Befort, B. L.: Global food demand and the sustainable intensification of agriculture, P. Natl. Acad. Sci. USA, 108, 20260-20264, doi:10.1073/pnas.1116437108, 2011.

Wang, Y., Jacob, D., and Logan, J.: Global simulation of tropospheric $\mathrm{O}_{3}-\mathrm{NO}_{\mathrm{x}}$-hydrocarbon chemistry, 1. Model formulation, J. Geophys. Res., 103, 10713-10726, 1998.

Wesley, M.: Parameterization of surface resistance to gaseous dry deposition in regional-scale numerical models, Atmos. Environ. 23, 1293-1304, 1989. 
World Health Organization (WHO): Air Quality Guidelines for Europe, 2nd Edn., Reg. Publ. Eur. Ser., Vol. 91, 288 pp., WHO Reg. Off. for Eur., Copenhagen, 2000.

Wu, S., Mickley, L. J., Kaplan, J. O., and Jacob, D. J.: Impacts of changes in land use and land cover on atmospheric chemistry and air quality over the 21 st century, Atmos. Chem. Phys., 12, 1597-1609, doi:10.5194/acp-12-1597-2012, 2012.
Yienger, J. J. and Levy, H.: Empirical model of global soil-biogenic $\mathrm{NO}_{\mathrm{x}}$ emissions, J. Geophys. Res., 100, 11447-11464, 1995. 